\title{
Friend or Foe: S100 Proteins in Cancer
}

\author{
Chantal Allgöwer ${ }^{1,+}{ }^{,}$Anna-Laura Kretz ${ }^{1, \dagger}$, Silvia von Karstedt ${ }^{2,3,4} \oplus$, Mathias Wittau ${ }^{1}$, \\ Doris Henne-Bruns ${ }^{1}$ and Johannes Lemke ${ }^{1, *(D)}$ \\ 1 Department of General and Visceral Surgery, Ulm University Hospital, Albert-Einstein-Allee 23, \\ 89081 Ulm, Germany; chantal.allgoewer@uni-ulm.de (C.A.); anna-laura.kretz@uni-ulm.de (A.-L.K.); \\ mathias.wittau@uniklinik-ulm.de (M.W.); sekretariat.chirurgie1@uniklinik-ulm.de (D.H.-B.) \\ 2 Department of Translational Genomics, Center of Integrated Oncology Cologne-Bonn, Medical Faculty, \\ University Hospital Cologne, Weyertal 115b, 50931 Cologne, Germany; s.vonkarstedt@uni-koeln.de \\ 3 CECAD Cluster of Excellence, University of Cologne, Joseph-Stelzmann-Straße 26, 50931 Cologne, Germany \\ 4 Center of Molecular Medicine Cologne, Medical Faculty, University Hospital of Cologne, Weyertal 115b, \\ 50931 Cologne, Germany \\ * Correspondence: johannes.lemke@uniklinik-ulm.de; Tel.: +49-731-500-53691 \\ + These authors contributed equally to this work.
}

Received: 29 June 2020; Accepted: 23 July 2020; Published: 24 July 2020

Abstract: S100 proteins are widely expressed small molecular EF-hand calcium-binding proteins of vertebrates, which are involved in numerous cellular processes, such as $\mathrm{Ca}^{2+}$ homeostasis, proliferation, apoptosis, differentiation, and inflammation. Although the complex network of S100 signalling is by far not fully deciphered, several S100 family members could be linked to a variety of diseases, such as inflammatory disorders, neurological diseases, and also cancer. The research of the past decades revealed that $\mathrm{S} 100$ proteins play a crucial role in the development and progression of many cancer types, such as breast cancer, lung cancer, and melanoma. Hence, S100 family members have also been shown to be promising diagnostic markers and possible novel targets for therapy. However, the current knowledge of S100 proteins is limited and more attention to this unique group of proteins is needed. Therefore, this review article summarises S100 proteins and their relation in different cancer types, while also providing an overview of novel therapeutic strategies for targeting S100 proteins for cancer treatment.

Keywords: S100 proteins; $\mathrm{Ca}^{2+}$-dependent signalling; biomarkers; cancer therapy

\section{The S100 Family}

In 1965, Blake W. Moore isolated a protein from the bovine brain to identify specific proteins of the nervous system. Since it was soluble in $100 \%$ saturated ammonium sulfate at neutral $\mathrm{pH}$, the protein was named "S-100" [1]. Isobe et al. later showed that this S100 protein formed a dimer, consisting of two homologous yet different molecules, defined as S100A and S100B [2,3]. Further research from the past decades revealed that their expression was not limited to nervous tissue but that $\mathrm{S} 100$ proteins are found in various tissues exclusively in vertebrates. Subsequently, many more S100-related proteins were discovered, and currently, 25 family members are known [4]. It has since been shown that these proteins are involved in a variety of different pathways, thereby playing a critical role in essential cellular processes, such as proliferation, apoptosis, differentiation, and inflammation [5].

\subsection{The S100 Family Members}

\subsubsection{Structure}

S100 proteins are classified as EF-hand motif calcium-binding proteins and represent the largest subgroup within the EF-hand superfamily [6]. Typically, S100 members form homodimers, and 
only a few heterodimers are known, such as Moore's S100A1/S100B protein and the S100A8/S100A9 dimer $[4,7]$. S100G is an exception to the rule, as it only exists as a monomer [7,8]. Van der Waals interactions stabilise the dimers, and the formation of higher-order oligomers is also observed $[6,8]$.

Each monomer is formed by two EF-hand motifs, of which each EF-hand motif consists of a $\mathrm{Ca}^{2+}$-binding loop flanked by $\alpha$-helices (helix-loop-helix) [9]. The N-terminal EF-hand (helix I-loop I-helix II) is S100-specific and has a lower $\mathrm{Ca}^{2+}$-binding affinity, due to 14 amino acid residues, while the canonical C-terminal EF-hand (helix III-loop II-helix IV) with 12 amino acid residues has a high $\mathrm{Ca}^{2+}$-binding affinity [9-11]. The two EF-hands are connected by a hinge region [9], and helix I and helix IV display the dimerisation interface [10]. When calcium binds to loop II of the C-terminal EF-hand, the orientation of helix III shifts and exposes a hydrophobic pocket, which is necessary for target binding $[6,7,11]$. An S100 homodimer is usually supplied with two symmetrical hydrophobic binding sites that recognise two identical target molecules [7,10,12]. S100A10 seems to be the only family member who is active in a calcium-independent manner, as it lacks a $\mathrm{Ca}^{2+}$-binding site and remains in an open conformation when calcium is absent $[5,7,13]$. Besides calcium, some S100 proteins, for example, S100A7, S100A12, and S100B are capable of binding other divalent metal ions such as zinc $\left(\mathrm{Zn}^{2+}\right)$, copper $\left(\mathrm{Cu}^{2+}\right)$, and manganese $\left(\mathrm{Mn}^{2+}\right)$, which is thought to play a role in the formation of oligomers [4,14]. Moreover, the sequestering of nutrient transition metals, such as $\mathrm{Zn}^{2+}$ and $\mathrm{Mn}^{2+}$, leads to the growth inhibition of microbial pathogens [6]. In this context, Nakashige et al. demonstrated that calprotectin (CP), an S100A8/S100A9 oligomer, is also capable of binding iron $\left(\mathrm{Fe}^{2+}\right)$ [15]. However, so far, this finding is ambiguous in comparison with previous studies $[16,17]$.

Although S100 family members share high sequence similarities [10] and show similar folding behaviour, they differ regarding their shape and charge [8]. The fact that S100 proteins show a wide diversity of target proteins is to be explained by the specific target binding sites [6,12], mainly differing in the hinge region and the C-terminal extension [9], as well as the individual expression profile of each S100 family member [6].

\subsubsection{Expression and Regulation}

So far, S100 proteins could only be found in vertebrates [6,8]. In humans, the genes for the S100A subfamily (S100A1-S100A16) are clustered on chromosome 1q21, while the genes of other S100 members are located on chromosomes 21q22 (S100B), Xp22 (S100G), 4p16 (S100P), and 5q13 (S100Z) [18,19]. Generally, an S100 gene consists of three exons and two introns, of which exon 1 is not translated, whereas exon 2 and exon 3 encode the EF-hand structures [20].

In contrast to Moore's initial hypothesis that $\mathbf{S 1 0 0}$ proteins are only expressed in the nervous system, it was shown that $\mathrm{S} 100$ family members are widely expressed across various tissues. However, each S100 family member seems to have a particular expression pattern, and expression levels vary from cell type to cell type. For example, S100A9 is primarily expressed in immune cells [21], while S100A3 is mainly found in hair cuticular cells [22]. Some S100 proteins are even expressed in a cell cycle-dependent manner, for example, S100A2 is nearly absent in the $\mathrm{G}_{0}$ phase, but expression increases in the early $G_{1}$ and $S$ phase within epithelial cells [23].

The clustered genes of the S100A subfamily on chromosome 1q21 are part of the epidermal differentiation complex (EDC) and thereby regulated by a pool of transcription factors (e.g., Klf4, Grhl3, Arnt) [24]. Nevertheless, the cell-specific expression of these genes indicates that other factors are involved in the regulation of the $S 100$ genes, In this context, epigenetic features such as DNA methylation could be observed. Although these epigenetic changes have not yet been fully understood, it is presumed that inter alia S100 genes are silenced by methylation of the cytosine within CpG pairs of regulatory regions [20]. Additionally, the expression of some S100 family members seems to be regulated by microRNA (miRNA). Choe et al. showed that S100A4 is negatively controlled by miRNA-124 [25]. Recently, Wen et al. described S100B downregulation by miR-135b in cerebral palsy rat models [26]. A better understanding of the physiology of S100 proteins also demonstrated that extracellular stimuli such as growth factors and cytokines, as well as intracellular signalling cascades, 
can influence S100 protein levels [27-29]. An overview of the different expression profiles of each S100 family member is given in Table A1, which can be found in the Appendix A.

Unlike other EF-hand proteins, S100 members can not only be found inside cells but also in the extracellular space and interacting with receptors [5]. A potential active mechanism of secretion has not been fully understood since S100 proteins lack the structural sequence for the classical endoplasmic reticulum (ER)/Golgi secretory pathway, but cellular events leading to membrane ruptures such as passive cellular necrosis or regulated types of necrosis or tubulin-dependent translocation are considered in this context [30,31].

\subsubsection{Functions}

S100 proteins interact with a high number of different targets and are thereby involved in various cellular processes, including $\mathrm{Ca}^{2+}$ homeostasis, proliferation, differentiation, apoptosis, inflammation, and cell migration [5]. The different functions of each S100 family member can be found in Table A1 in the Appendix A.

$\mathrm{Ca}^{2+}$ is involved in almost every cellular process, and elevated $\mathrm{Ca}^{2+}$ concentrations lead to cell death. Therefore, tight regulation of $\mathrm{Ca}^{2+}$ levels is essential [32]. $\mathrm{S} 100$ proteins secure cellular $\mathrm{Ca}^{2+}$ homeostasis not only by binding and transporting free intracellular $\mathrm{Ca}^{2+}$ to and from the plasma membrane, but also by interacting with transmembrane proteins such as the plasma membrane $\mathrm{Ca}^{2+}$ transport ATPase (PMCA1b), the transient receptor potential vanilloid 6 (TRPV6), and the $\mathrm{Na}^{+} / \mathrm{Ca}^{2+}$ exchanger (NCX1) [32-35]. A prominent example is S100A1, as it modulates the contractile performance of cardiomyocytes by interacting with the sarcoplasmic reticulum ATPase (SERCA2a) and the myocardial ryanodine receptor 2 (RyR2), which improves the systolic release and diastolic uptake of $\mathrm{Ca}^{2+}[36,37]$.

Furthermore, the S100 family is involved in inflammation and immune response. S100A8, S100A9, and S100A12 fulfil the characteristics of danger-associated molecular patterns (DAMPs), also called alarmins [38,39]. DAMPs are danger signals released by damaged, infected, or dying cells and trigger an inflammatory response [39]. The majority of extracellular S100 proteins interact with the receptor for advanced glycation end products (RAGE) and Toll-like receptor 4 (TLR4). The binding of S100A9, S100A8/S100A9, and S100A12 to these receptors stimulates nuclear factor "kappa-light-chain-enhancer" of activated B-cells (NF-kB) signalling, which results in the upregulated expression of cytokines and pro-inflammatory factors, such as interleukin-1 $\beta$ (IL-1 $\beta$ ) or tumour necrosis factor $\alpha$ (TNF $\alpha)[29,40,41]$. Further, it was shown that S100A7, S100A8, S100A9, and S100A15 have chemotactic features, attracting neutrophils and lymphocytes $[23,28,40,42,43]$. S100A7, S100A12, and S100A15 additionally support the initial immune response by reducing the survival of pathogens such as Escherichia coli (E. coli) [23,28]. In principle, S100B does not act chemotactically, but extracellular S100B was found to encourage microglia migration by stimulating the expression and release of chemokines [44].

The promotion of proliferation by $\mathrm{S} 100$ proteins is also often mediated in a RAGE-dependent manner, inducing NF- $\mathrm{KB}$ and mitogen-activated protein kinase (MAPK) signalling. This leads to the transcription of growth factors and survival proteins [45-48]. While extracellular S100A11 also induces RAGE-mediated transcription of the epidermal growth factor (EGF), intracellular S100A11 regulates the inhibition of proliferation $[49,50]$. To this end, S100A11 binds to nucleolin, which then allows the transcription of p21, resulting in the inhibition of DNA synthesis [50].

Additionally, it was shown that some S100 proteins, namely S100A2, S100A4, S100A14, and S100B interact with p53 [51-54]. The transcription factor p53 is an important tumour suppressor, and among other functions also regulates DNA replication and induces the transcription of pro-apoptotic proteins such as phorbol-12-myristate-13-acetate-induced protein 1 (NOXA) and p53 upregulated modulator of apoptosis (PUMA) [55]. Thereby, S100 proteins can be linked to the regulation of intrinsic apoptosis. S100A6 and S100A14 activate RAGE-mediated production of reactive oxygen species (ROS), also resulting in cell death $[27,46]$. 


\subsection{Clinical Relevance of S100 Proteins}

Although the function of some family members (e.g., S100Z) remains unknown and the complex roles of S100 proteins are not yet fully unravelled, the diversity and importance of S100 proteins are widely accepted. Consequently, any dysregulation can have severe outcomes, and S100 proteins are linked to numerous pathologic conditions and diseases. Therefore, they also show to be promising markers for diagnostic and possible novel targets for therapy, as to be discussed in the following chapter.

As previously described, S100 proteins are involved in inflammation and immune response. Therefore, it is comprehensible that $\mathrm{S} 100$ proteins also play a role in inflammatory disorders. Rheumatoid arthritis (RA) is the most common rheumatic disease and destroys bone and cartilage due to chronic inflammation [56]. Especially the family members S100A8 and S100A9 seem to be key molecules in the progress of RA due to their role as DAMPs. S100A8/S100A9 levels are useful biomarkers to monitor the disease, and serum concentrations can predict the response to therapeutic drugs such as methotrexate, a commonly used drug for RA treatment, and adalimumab, a TNF $\alpha$-blocking antibody [56-58]. The testing of S1008/S100A9 in stool samples is an established method to diagnose inflammatory bowel diseases (IBDs), a chronic inflammatory disease of the gut. Although it is not possible to discriminate between different types of bowel disease based on S100A8/S100A9 testing, this non-invasive method is very accurate and favoured in the pediatric field $[59,60]$. Additionally, S100 family members could also be linked to allergies, cystic fibrosis, psoriasis, and several other inflammatory diseases [61].

Pathologic S100 concentrations can also be detected in neurological diseases [61]. The Scandinavian Neurotrauma Committee (SNC) recommends using S100B as a biomarker in addition to the classical anamnesis to identify patients with a high risk for intracranial injuries (ICI) after a mild traumatic brain injury (TBI) [62]. In this context, serum S100B demonstrates high sensitivity for the detection of ICI after mild TBI and analysing S100B levels brings great benefits, since only $8 \%$ of patients with mild TBI suffer from ICIs. Therefore, the application of cost-intensive computerised tomography (CT) can be reduced, and patients are protected from unnecessary exposure to radiation $[63,64]$. Changes in S100B levels were also found in patients with psychiatric diseases, such as schizophrenia, depression, and bipolar disorder, but more studies are needed to establish S100B as a reliable clinical biomarker [65]. Evaluated levels of several S100 proteins could also be observed in the brain of Alzheimer's patients. These S100 family members, namely S100A1, S100A6, S100A7, S100A8, S100A9, S100A12, and S100B, seem to be involved in the progression of Alzheimer's disease (AD), including the formation of amyloid aggregates, and could thereby be promising regarding new therapeutic approaches [66].

S100A1 seems to be an essential factor concerning cardiological diseases since it is involved in the contractile performance of cardiomyocytes [36,37]. Fan et al. demonstrated that patients showing ST-segment elevation myocardial infarction (STEMI) in the electrocardiogram (ECG) also had increased levels of S100A1 and that this S100 family member could complement current biomarkers [67]. It was also shown that S100A1 concentrations rise during early-stage acute myocardial ischemia, followed by a quick decrease, and thereby S100A1 could represent an early biomarker [68]. In addition, studies with S100A1 gene therapy in animal models predict a promising new strategy for the treatment of heart failure [69].

Furthermore, changes in S100 expression could also be observed in several cancer types, and S100 proteins seem to play a crucial role in the development of tumours. This context will be discussed in detail in the following section.

\section{S100 Proteins in Cancer}

In the 1980s, soon after the identification of the first S100 family members, the presence of S100 proteins was also observed in different cancer types, drawing rising attention to this group of calcium-binding proteins within the oncological field. In this context, S100 expression was, for example, detected in metastatic melanoma [70,71], renal cell carcinoma [72], and breast cancer [73]. Moreover, an S100 protein expressed in mouse Ehrlich ascites-tumour cells was identified as S100A6 [74], and S100P was found in the cell nuclei of brain tumours [75]. Further research from the past decades 
demonstrated that dysregulation of S100 proteins, typically upregulation, can be connected to tumour growth, angiogenesis, and metastasis [76]. Several S100 proteins could also be linked to drug resistance and seem to be involved in mediating the response to chemotherapy [77]. Each cancer type shows a specific S100 expression profile, and the different S100 family members function individually in a tissue-dependent manner. S100A2, for example, operates as a tumour suppressor in oral cancer while it promotes tumour growth in lung cancer [78]. The role of S100 proteins has been widely examined in breast cancer, lung cancer, and melanoma, but pathologic S100 signalling could also be observed in additional cancer types, such as ovarian, colorectal, and pancreatic cancer.

\subsection{S100 Proteins in Breast Cancer}

Breast cancer is the most common cancer type among women [79], and especially metastatic breast cancers are highly lethal [80]. It was shown that several S100 family members, including S100A2, S100A4, S100A6, S100A7, S100A8, S100A9, and S100A11 are up- or downregulated in breast cancer compared with healthy tissue, suggesting that S100 proteins play a crucial role in tumour development and progression [81,82] and as predictive biomarkers [83-88].

Zhang et al. analysed S100 mRNA expression in breast cancer patients $(n=1117)$, using the online databank Gene Expression Omnibus. Intriguingly, the expression of S100 proteins correlates with the overall survival (OS) of patients, depending on cancer subtype and clinicopathologic features. For example, high mRNA levels of S100A8 and S100A9 predict worse prognosis in the luminal A-type breast cancer, while increased levels of S100A10, S100P, and S100Z showed shorter OS in patients with the basal-like subtype. In contrast, longer OS was observed for patients with luminal a subtype expressing high levels of S100A1, S100A2, and S100A6 and for patients with the basal-like subtype expressing high levels of S100A14. Overall, S100A1 and S100A6 seem to predict better prognosis and S100A8, S100A9, S100A11, and S100P seem to worsen OS rates [84]. Zhong et al. found a correlation between S100A8 and lymph node metastasis in breast cancer and therefore, tumour progression [85]. Further publications covering this connection identified S100B as a serum marker in endocrine-resistant breast cancer [86] and elevated S100B serum levels as a negative prognostic value for breast cancer [87,88]. Nevertheless, a collective expression pattern of all S100 members together might have higher prognostic value than the single proteins [82].

S100A4 is highly involved in metastasis and invasion of many different cancer types, including breast cancer $[89,90]$. Barraclough et al. early showed that S100A4 is associated with a metastatic phenotype using a rat mammary model. It was suggested that the underlying mechanism includes the interaction of S100A4 with cytoskeletal proteins, such as actin and myosin, thereby promoting cell motility [91]. These findings are supported by further studies, showing that intracellular S100A4 interacts with actin, non-muscle myosin heavy chain IIA (NMIIA), and tropomyosin, leading to cell migration [92,93]. Although S100A1 does not seem to be directly involved in breast cancer signalling, it was shown that S100A1 reduces the activity of intracellular S100A4 [94]. The interaction between S100A4 and matrix metalloproteinase 2 (MMP2) induces epithelial-mesenchymal transition (EMT), which is considered to be an initial step during invasion and metastasis [95]. S100A4 can not only be found in cancer cells but is also highly expressed in stromal cells of the tumour microenvironment (TME), such as fibroblasts, T-cells, macrophages, and neutrophils [81,96]. Extracellular S100A4 in the TME induces the release of pro-inflammatory factors (e.g., interleukin 6 (IL-6), interleukin 8 (IL-8), and C-X-C motif chemokine 10 (CXCL10)), which then converts monocytes into tumour-associated macrophages (TAMs), resulting in metastasis and drug resistance [97].

Only a few studies have been performed to investigate the signalling of S100A6 in breast cancer. However, S100A6 induces the activity of calcyclin-binding protein/Siah-1-interacting protein (Cacy/SIP), which is involved in tumour invasion and metastasis in breast cancer most likely by increasing $\beta$-catenin levels $[98,99]$. Another exciting approach showed that S100A6 levels decrease in human breast cancer cell line MDA-MB-231 when treated with anti-tumour agents, namely tumour 
necrosis factor-related apoptosis-inducing ligand (TRAIL) and etoposide, indicating that S100A6 might be a potential biomarker for apoptosis during therapy [100].

S100A7 was also identified as an essential protein in breast cancer cells, especially in estrogen receptor $\alpha(E R \alpha)$ negative cells, where the binding to RAGE leads to activation of extracellular signal-regulated kinase (ERK) and NF- $\mathrm{KB}$ signalling, resulting in tumour growth and enhanced metastasis [101]. Moreover, increased NF-kB activity was observed in S100A7-overexpressing breast cancer cells, associated with evaluated levels of NF- $\mathrm{kB}$ target genes matrix metalloproteinase 9 (MMP9) and vascular endothelial growth factor (VEGF), resulting in proliferation and invasion [102]. Further, the binding of S100A7 and RAGE leads to the recruitment of TAMs, which then promote further tumour growth, angiogenesis, and metastasis by expressing chemokine (C-C motif) ligand 2 (CCL2), cyclooxygenase-2 (COX2), and VEGF [101,103]. Intracellular S100A7 interacts with the transcriptional cofactor constitutive photomorphogenesis 9 (COP9) constitutive photomorphogenic homolog subunit 5 (COPS5), also known as c-Jun activation domain-binding protein-1 (Jab1), which then accumulates in the nucleus and promotes the expression of AP-1 and NF- $\mathrm{kB}$, resulting in enhanced tumour growth and invasion [104].

The binding of S100A8/S100A9 to RAGE promotes breast cancer cell growth by inducing MAPK signalling. In addition, RAGE then mediates cell migration by promoting actin polymerisation and EMT, resulting in metastasis and invasion [105]. Although not all S100 proteins have been studied intensively in this context, the current knowledge of S100 signalling in breast cancer is summarised in Figure 1.

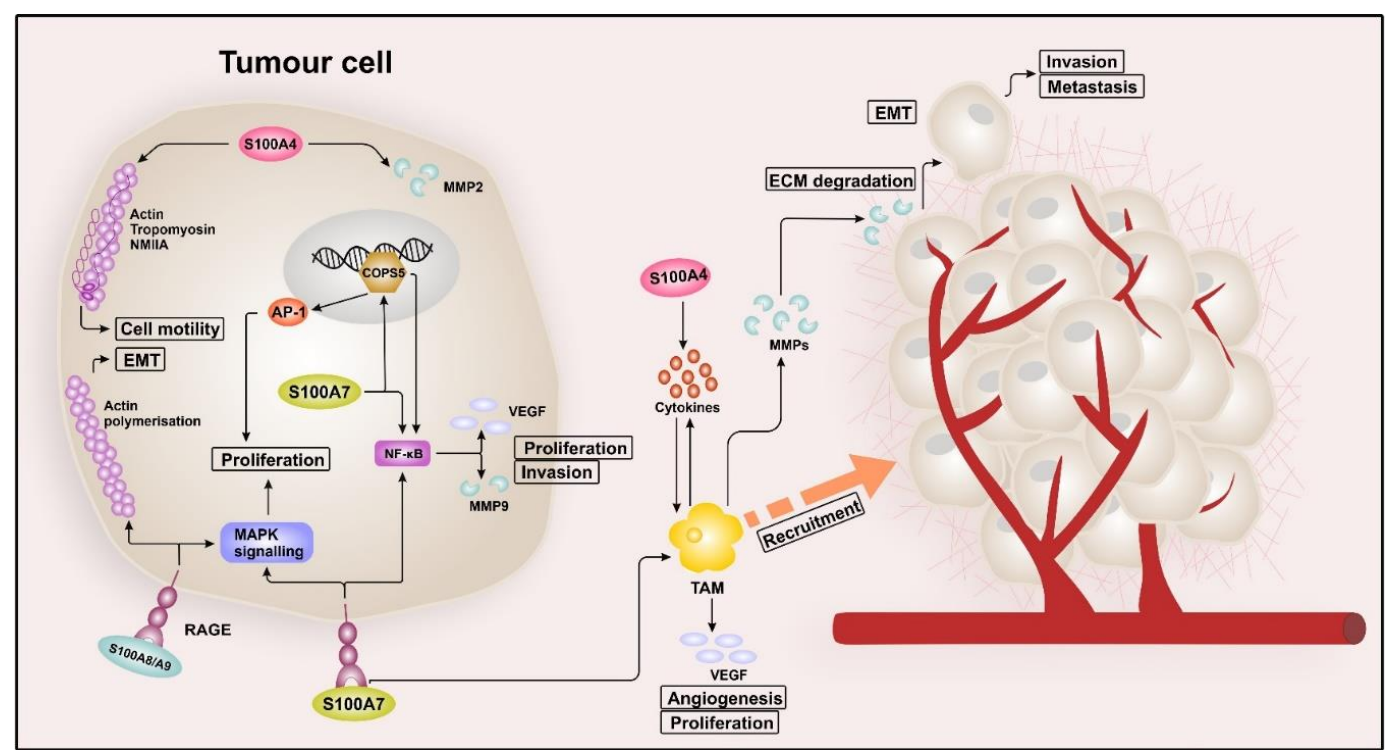

Figure 1. S100 signalling in breast cancer. Intracellular S100A4 interacts with cytoskeletal proteins, such as actin, non-muscle myosin heavy chain IIA (NMIIA), and tropomyosin, which promotes cell motility. Besides, S100A4 can induce epithelial-mesenchymal transition (EMT) by regulating the expression of matrix metallopeptidases 2 (MMP2), leading to invasion and metastasis. Extracellular S100A4, located in the tumour microenvironment (TME), induces the release of pro-inflammatory factors (e.g., IL-6, IL-8, and CXCL10). These cytokines then convert monocytes into tumour-associated macrophages (TAMs), which in return, promote EMT, proliferation, and drug resistance of the tumour cells. The binding of extracellular S100A7 to the receptor for advanced glycation end products (RAGE) induces mitogen-activated protein kinase (MAPK) and nuclear factor "kappa-light-chain-enhancer" of activated B-cells (NF- $\kappa$ B) signalling, resulting in tumour growth and metastasis. Increased NF- $\mathrm{B}$ activity was observed in S100A7-overexpressing breast cancer cells, associated with evaluated levels of matrix metalloproteinase 9 (MMP9) and vascular endothelial growth factor (VEGF), resulting in proliferation 
and invasion. The binding of S100A7 and RAGE also leads to the recruitment of TAMs, which then promote further tumour growth, angiogenesis, and metastasis by expressing chemokine (C-C motif) ligand 2 (CCL2), cyclooxygenase-2 (COX2), and VEGF. Intracellular S100A7 interacts with the transcriptional cofactor COP9 constitutive photomorphogenic homolog subunit 5 (COPS5), which in turn promotes the expression of AP-1 and NF- $\mathrm{B}$, resulting in enhanced tumour growth and invasion. S100A8/S100A9 enhances breast cancer cell growth by inducing MAPK signalling in a RAGE-dependent manner. In addition, RAGE mediates cell migration by promoting actin polymerisation and EMT, leading to metastasis and invasion.

\subsection{S100 Proteins in Lung Cancer}

Lung cancer is the most common cancer type with a high mortality rate [79], mostly due to lacking diagnostic means for efficient early detection [106]. There are two major groups of lung cancer: non-small cell lung cancer (NSCLC), which is diagnosed in about $80 \%$ of all lung cancer patients, and small cell lung cancer (SCLC) $[107,108]$. It was shown that S100A1, S100A2, S100A3, S100A4, S100A6, S100A7, S100A8/S100A9, S100A10, S100A11, S100B, and S100G are overexpressed in NSCLC, and except S100B, all are predictive for poor survival [109]. The function of several S100 proteins in lung cancer remains unclear. However, some family members have been studied in this context and are summarised in Figure 2.

The studies on S100A2 in NSCLC presented conflicting data [110]. For example, Feng et al. showed that S100A2 was downregulated in NSCLC cell lines and detected CpG methylation in the promoter region of the S100A2 gene, indicating that S100A2 was suppressed during early-stage carcinogenesis [111]. In contrast, Heighway et al. demonstrated that S100A2 was strongly expressed in primary NSCLC tissue [112], and Bulk et al. later showed that S100A2 acts as a metastasis inducer in mouse models [113]. In 2014, Hountis et al. introduced a dual role concept for S100A2 in lung cancer, implicating that S100A2 is primarily expressed in the nucleus at an early stage of NSCLC, where it mediates resistance to p53-dependent apoptosis and inhibits tumour-promoting genes (e.g., PA1-1 and vimentin) and in later stages relocates to the cytoplasm in a $\mathrm{Ca}^{2+}$-dependent manner [114].

S100A4 seems to be an important player in the development and metastasis of lung cancer, promoting tumour cell proliferation and motility $[115,116]$. The overexpression of S100A4 in lung adenocarcinoma (ADC), a subtype of NSCLC, was linked to reduced OS of these patients [117]. In vitro studies revealed that extracellular S100A4 inhibited autophagy and induced Wnt signalling in a RAGE-dependent manner and intracellular S100A4 additionally activated $\beta$-catenin, resulting in increased proliferation and enhanced viability of lung cancer cells [118]. Further, in vitro studies showed that the depletion of S100A4 resulted in decreased NF- $\mathrm{kB}$ signalling and inhibition of matrix metalloproteinases 9 (MMP9), demonstrating that the S100A4/NF- $\mathrm{kB} / \mathrm{MMP} 9$ signalling axis promotes invasion [117].

Regarding the role of S100A7 in lung cancer, it was shown that this protein is highly expressed in lung squamous cell carcinoma (SCC), an NSCLC subtype, and that knockdown of S100A7 resulted in decreased NF-KB-dependent cell proliferation [119]. In vitro, Wang et al. demonstrated that S100A7 expression was induced by the Hippo pathway and depletion of S100A7 lead to suppression of DNp63, a marker for SSC, while the ADC markers TFF1 and napsin A were upregulated, and an inverse correlation of S100A7 and yes-associated protein (YAP) was observed. In summary, these data implicate that S100A7 is an essential player in cellular plasticity and ADC to SSC transdifferentiation [120].

S100B was introduced as a possible biomarker for brain metastasis in lung cancer patients [121,122]. Further investigation of S100B in an ADC-derived brain metastasis cell line showed that depletion of S100B resulted in the downregulation of pro-survival factors, namely B-cell lymphoma 2 (Bcl-2) and B-cell lymphoma extra-large (Bcl-xL), both inhibitors of apoptosis, indicating that S100B suppresses apoptosis in these cancer cells. In this study, it was moreover observed that S100B correlates with enhanced proliferation, migration, and invasion [123]. In contrast, Liu et al. showed that increased mRNA levels of S100B predicted better OS in patients with NSCLC [109]. Therefore, the molecular 
mechanisms of S100B in lung cancer need to be further evaluated to classify this protein in a clinical context.

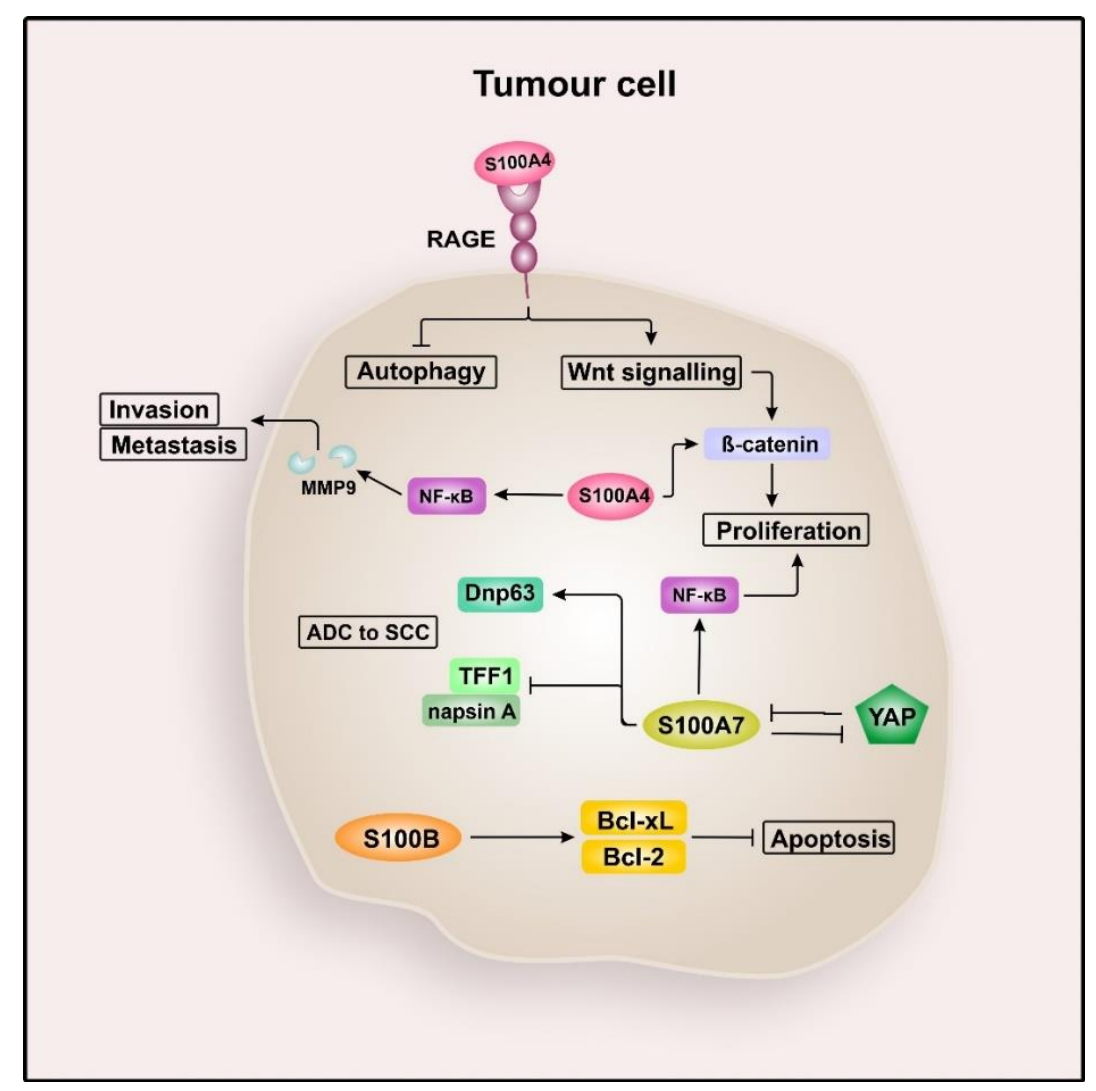

Figure 2. S100 signalling in lung cancer. Extracellular S100A4 inhibits autophagy and induces Wnt signalling by interacting with the receptor for advanced glycation end products (RAGE) and intracellular S100A4 additionally activates $\beta$-catenin, resulting in increased proliferation and enhanced viability of lung cancer cells. S100A4 also induces the expression of (MMP9) by activating nuclear factor "kappa-light-chain-enhancer" of activated B-cells (NF- $\mathrm{B}$ ), thereby promoting invasion and metastasis. S100A7 is most likely involved in adenocarcinoma (ADC) to squamous cell carcinoma (SSC) transdifferentiation of lung cancer cells, by upregulating the SSC marker DNp63 and downregulation of the ADC markers thyroid transcription factor 1 (TTF1) and aspartic proteinase napsin (napsin A). In this context, an inverse correlation of S100A7 and yes-associated protein (YAP) was observed. Moreover, S100A7 seems to activate NF-kB-dependent cell proliferation. Within lung cancer-derived brain metastasis cells, S100B was shown to upregulate the expression of B-cell lymphoma 2 (Bcl-2) and B-cell lymphoma extra-large (Bcl-xL), indicating that S100B is capable of suppressing apoptosis.

\subsection{S100 Proteins in Malignant Melanoma}

Malignant melanoma arises from mutated melanocytes, and although melanoma is exceedingly rare ( $<2 \%$ of all skin malignant tumours), it is the deadliest form of skin cancer $[124,125]$. The expression of several S100 family members, namely S100A1, S100A2, S100A4, S100A6, S100A7, S100A8, S100A9, S100A10, S100A11, S100A13, and S100B, were detected in melanoma tissue, partially depending on the cancer stage $[76,126]$.

As previously discussed, S100A4 is involved in the metastatic processes in other cancer types, and similar observations were made in melanoma. Upregulation of S100A4 correlates with the upregulation of RAGE in metastatic melanoma cells in vitro, and elevated levels of S100A4 and RAGE are associated with high tumour burden in vivo [127,128]. It was shown that extracellular S100A4 activates NF-KB in a RAGE-dependent manner, resulting in the release of TNF $\alpha$ [129]. S100A4 also induces the secretion of further paracrine factors, such as IL-8 and CCL2, which in return, promote angiogenesis and recruitment 
of monocytes, creating an inflammatory milieu in the tumour microenvironment [130]. Moreover, it was revealed that extracellular S100A4 decreases the expression of occludin and VE-cadherin in endothelial cells (ECs), thereby disrupting cell-cell adhesion. This enables melanoma cells to transmigrate through the EC monolayer into the bloodstream [128]. In summary, S100A4 induces metastatic signalling and promotes cell migration in malignant melanoma.

When monitoring stage IV melanoma patients during immunotherapy with ipilimumab, the heterodimer S100A8/S100A9 attracted attention, as high serum levels of it in early stages of treatment predicted worse response [131]. The release of S100A8/S100A9 can be induced by UV radiationexposed keratinocytes, and extracellular S100A8/S100A9 then promotes proliferation and migration of melanocytes via RAGE-dependent signalling [132]. It could be demonstrated that interaction between S100A8/S100A9 and RAGE leads to increased levels of the metalloproteinases MMP2, MMP9, and MMP14 in melanoma cells, which enhances metastatic properties [133]. Besides RAGE, novel ligands for S100A8/S100A9 were found. S100A8/S100A9 binds to the melanoma cell adhesion molecule (MCAM), a highly expressed cell adhesion molecule in melanoma [134]. This interaction activates mitogen-activated protein kinase kinase kinase 8 (MAP3K8), also termed tumour progression locus 2 (TPL2), which conversely stimulates the transcription factor ETS translocation variant 4 (ETV4), leading to induction of MMP25 and promoting melanoma lung metastasis [135]. The homodimer of S100A9 additionally interacts with extracellular matrix metalloprotease inducer (EMMPRIN), which activates TNF receptor-associated factor (TRAF2)-dependent NF- $\mathrm{kB}$ signalling and the upregulation of cytokines such as TNF $\alpha$, CXCL1, CXCL2, and CXCL3, resulting in metastasis [136]. MCAM and EMMPRIN are both highly expressed in melanoma and inhibition of the interaction between these receptors and S100A8/A9 could suppress lung metastasis in vivo, thereby representing an interesting target for therapeutic approaches [137].

S100B is described to be a prognostic marker for the advanced stages of melanoma, especially for distant metastasis, and increased serum S100B levels are associated with shorter disease-free survival (DFS) and OS [138-140]. Investigating the molecular mechanisms of S100B in melanoma cells, it could be revealed that S100B interacts with ribosomal S6 kinase (RSK). RSK is a downstream target of ERK, and S100B inhibits phosphorylation of RSK by ERK in a $\mathrm{Ca}^{2+}$-dependent manner so that RSK remains in the cytoplasm and does not relocate to the nucleus. This results in increased activity of RSK in the cytoplasm, leading to improved tumour survival [141]. In vitro studies also revealed that increased levels of p53 in malignant melanoma cells promote expression of S100B, and within a negative feedback loop, S100B inhibits p53 activity at the protein level, thereby preventing p53-dependent apoptosis [54,142]. While p53 is mutated in most cancer types, $80 \%$ of melanomas express wild-type p53 [143], and therefore S100B might be an attractive target for new therapeutic approaches in this context. An overview of S100 signalling in malignant melanoma is given in Figure 3. 


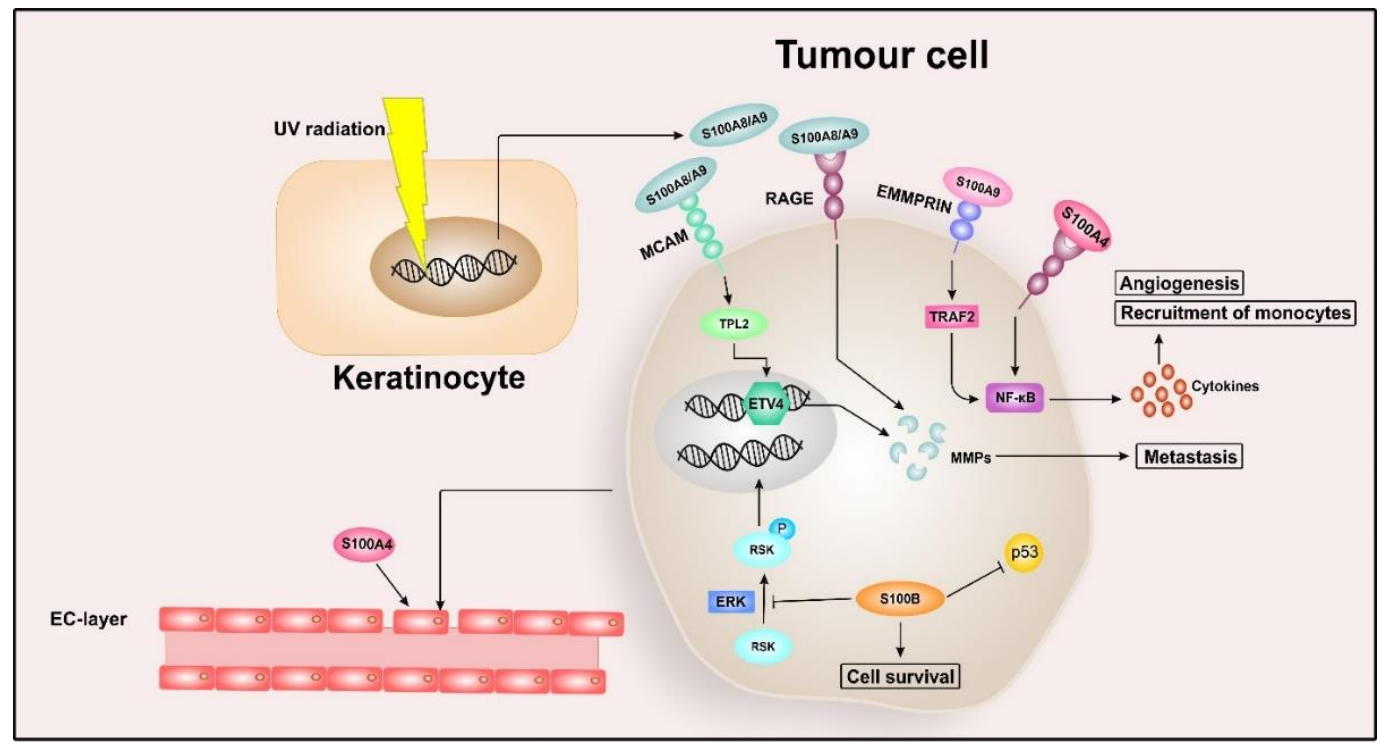

Figure 3. S100 signalling in melanoma. Extracellular S100A4 binds to the receptor for advanced glycation end products (RAGE) and thereby activates nuclear factor "kappa-light-chain-enhancer" of activated B-cells (NF-kB), resulting in the release of cytokines such as tumour necrosis factor $\alpha(\mathrm{TNF} \alpha)$. These cytokines then promote angiogenesis and recruitment of monocytes, creating an inflammatory milieu in the tumour environment. Furthermore, extracellular S100A4 also decreases the expression of occluding and vascular endothelial cadherin (VE)-cadherin in endothelial cells (ECs), thereby disrupting cell-cell adhesion and enabling the tumour cells to transmigrate through the EC monolayer into the bloodstream. The release of S100A8/S100A9 can be induced by UV radiation-exposed keratinocytes, and extracellular S100A8/S100A9 then promotes proliferation and migration of melanocytes via RAGE signalling. The interaction between S100A8/S100A9 and RAGE can lead to increased levels of the metalloproteinases MMP2, MMP9, and MMP14 in melanoma cells, thereby enhancing metastatic properties. In addition to RAGE, S100A8/A9 also binds to the melanoma cell adhesion molecule (MCAM), thereby activating tumour progression locus 2 (TPL2) and stimulating the transcription factor ETS translocation variant 4 (ETV4), leading to the induction of MMP25 and promoting melanoma lung metastasis. The homodimer of S100A9 additionally interacts with extracellular matrix metalloprotease inducer (EMMPRIN), which activates TNF receptor-associated factor (TRAF2)-dependent NF- $\mathrm{B}$ signalling and the upregulation of cytokines such as TNF $\alpha$, chemokine (C-X-C motif) ligand 1 (CXCL1), CXCL2, and CXCL3, resulting in metastasis. S100B inhibits the phosphorylation of ribosomal S6 kinase (RSK) by extracellular signal-regulated kinase (ERK) in a $\mathrm{Ca}^{2+}$-dependent manner so that RSK remains in the cytoplasm, leading to improved tumour survival. S100B also inhibits p53 activity at the protein level, thereby preventing p53-dependent apoptosis.

\subsection{S100 Proteins in Ovarian Cancer}

Recent studies investigating mRNA expression of S100 proteins in correlation with the survival of ovarian cancer patients demonstrated that high levels of the S100 family members S100A2, S100A10, S100A11, S100A15, S100A16, and S100B predict worse OS, while S100A1, S100A3, S100A5, S100A6, S100A13, S100G, and S100Z are associated with longer OS, partially depending on cancer subtype and clinicopathological features [144,145]. However, the underlying mechanisms of these S100 proteins in the context of ovarian cancer have not yet been fully understood.

Nevertheless, among others, S100A3, S100A10, and S100B were identified to be related to drug resistance in ovarian cancer [146-148]. Elevated expression of S100A3 was found primarily in ovarian cancer cells resistant to cisplatin and paclitaxel, both standard chemotherapeutic drugs, as well as topotecan, a chemotherapeutic agent commonly used in second-line treatment [146]. S100A10 was 1 of 11 genes associated with multidrug resistance in ovarian primary serous carcinoma tissue, although further studies are needed to validate these data, as this relation could not be confirmed in a group 
with a smaller sample size [147]. In vitro studies could demonstrate that S100B contributes to cisplatin resistance in ovarian cancer stem cells (OCSC) by inhibiting p53 and therefore promoting multidrug resistance gene 1 (MDR1) and MDR-associated protein 1 (MRP1) [148,149].

Moreover, it was shown that ovarian cancer patients with high expression of cytoplasmic S100A10 and stromal Annexin A2 have a 3.4-fold increased risk of progression and a 7.9-fold higher risk of cancer-related death [150]. Annexin A2 and S100A10 form a heterotetramer referred to as AIIt, which interacts with the tissue plasminogen activator (tPA). This leads to the production of plasmin, which results in ECM degradation, EMT, and angiogenesis [151,152]. In addition, S100A10 is able to promote MMPs, altogether provoking cell migration and invasion [153].

\subsection{S100 Proteins in Colorectal Cancer}

Mounting evidence suggests that $\mathrm{S} 100$ proteins play a crucial role in colorectal carcinogenesis, through promoting proliferation, migration, and invasion [154]. Several S100 family members seem to be promising biomarkers, for example, high expression of S100A4 is associated with poor survival and increased aggressiveness when studying colorectal carcinoma (CRC) patients [155,156]. S100A8/A9 could be a reliable marker for diagnosis, and postoperative monitoring of CRC [157] and S100B can predict early relapse in stages II and III postoperative colon cancer patients [158].

Regarding the role of S100A4 in colorectal cancer, it comes as no surprise that this protein seems to be related to metastasis, as similar observations were made in other cancer types, such as breast and lung cancer $[90,115,159]$. It was shown that extracellular S100A4 promotes ERK and hypoxia signalling in a RAGE-dependent manner, mediating colon cancer cell motility [160]. Further, S100A4 is capable of activating the phosphoinositide 3-kinase/Akt/mechanistic target of the rapamycin pathway (PI3K/Akt/mTOR), leading to increased levels of VEGF and decreased E-cadherin, which triggers tumour progression and cell migration [161].

Furthermore, high protein expressions of S100A8 and S100A9 were found to be associated with differentiation and lymph node metastasis in CRC tissue. This overexpression correlates with increased levels of $\beta$-catenin [162]. Additionally, S100A8/A9 interaction with RAGE activates NF-kB and MAPK signalling, leading to upregulation of chemokines, such as CXCL1, CLC5, and CLC7, resulting in the formation of a premetastatic niche and tumour progression [163].

Recent studies also unravelled the involvement of S100P in tumorigenesis, metastasis, and invasion of CRC [164]. In this context, thioredoxin-1 (Trx-1) and $\beta$-tubulin were introduced as novel downstream targets of S100P, and interaction between these proteins led to improved cell viability and promotion of cell migration $[165,166]$.

\subsection{S100 Proteins in Pancreatic Cancer}

S100 proteins were shown to be involved in tumour progression and metastasis of pancreatic cancer $[164,167]$. S100A2, for example, is overexpressed in pancreatic cancer tissue and seems to be a good predictor regarding the response to pancreatectomy of pancreatic cancer patients $[168,169]$. S100A6 was found to be overexpressed, especially in the early phase of carcinogenesis, and high nuclear S100A6 levels predict poor survival of pancreatic cancer patients [170,171]. Similar observations were made for S100A11, as the expression is detected in the earlier stages and seems to decrease during tumour progression [172]. Besides, it has been suggested that the expression of S100A11 correlates with poor prognosis of pancreatic cancer patients after surgical resection [173]. Furthermore, evidence indicated that S100P could be a helpful marker for the diagnosis of pancreatic cancer, as it is specifically expressed in cancer cells [174,175].

Several studies also introduced S100A4 as a potential biomarker, as its expression correlates with malignancy, metastasis, invasion, and overall poor prognosis in pancreatic cancer [176-178]. Furthermore, it was found that S100A4 is overexpressed in pancreatic adenocarcinoma, most likely due to hypomethylation at intron 1 of the S100A4 gene [179]. S100A4 promoted cell growth and cell motility and inhibited apoptosis in vitro $[180,181]$. The knock-down of S100A4 did not only induce 
apoptosis but also increased gemcitabine sensitivity [182]. By studying the underlying mechanisms of S100A4 in pancreatic cancer, it could be shown that S100A4 is upregulated by sonic hedgehog (Shh)-Gli-1 signalling as part of the hedgehog pathway, eventually resulting in EMT and further leading to metastasis [183]. Recent in vivo studies, including an orthotopic human pancreatic cancer xenograft mouse model, revealed that S100A4 activates focal adhesion kinase (FAK) and Src kinase, both involved in tumour progression and metastasis [184].

High expression of S100A8 and S100A9 was found in the stroma cells, mainly monocytes, of pancreatic cancer, and the number of S100A8 positive stroma cells correlated with the Smad4 status of the tumour. Smad4 is a key mediator for TGF $\beta$, a pro-apoptotic protein involved in pancreatic tumour progression, and tumours without Smad4 expression showed a decreased number of S100A8+ stroma cells $[185,186]$. However, further studies are needed to fully understand the underlying mechanisms.

\subsection{S100 Proteins in Other Cancer Types}

A link between S100 proteins and additional cancer types, such as prostate cancer, bladder cancer, liver cancer, and oral cancer, could be made, although these relations have not yet been examined as closely as in previously described cancer types. Nevertheless, the current knowledge of S100 family members in these cancer diseases will be summarised in the following chapter.

In prostate cancer, S100A8 and S100A9 are upregulated and might be helpful markers in the early stage of prostate tumour progression [187]. In vitro studies showed that the heterodimer S100A8/A9 is secreted by prostate cancer cells, and extracellular S100A8/A9 activates NF-KB and MAPK signalling [188]. In contrast, $\mathrm{S} 100 \mathrm{~A} 6$ is present in prostate basal cells but absent in malignant prostate cells, indicating that S100A6 could expand the current spectrum of biomarkers for diagnosis [189]. However, more studies are needed to validate these findings and to further understand the role of S100 proteins in prostate cancer.

PCR-based analysis of human bladder cancer tissue showed that mRNA levels of S100A2, S100A3, S100A5, S1007, S100A8, S100A9, S100A14, S100A15, S100A16, and S100P were elevated, while S100A1, S100A4, and S100B were downregulated compared with normal bladder urothelium [190]. However, it is important to notice that only small sample size $(n=10)$ was examined and that a repeat of this study with a greater sample size could improve statistical stability. Nevertheless, the expression of S100A8 in bladder cancer was associated with disease progression in non-muscle-invasive bladder cancer (NMIBC) in more recent studies [191,192]. Investigating S100 proteins in bladder cancer also revealed a correlation between S100P and drug resistance, as decreased S100P levels were found in cisplatin-resistant bladder cancer cells, whereas overexpression of S100P increased sensitivity to cisplatin [193].

The role of S100 proteins in hepatocellular carcinoma (HCC), the most common form of primary liver cancer [194], is poorly understood so far. However, it was shown that high expression of S100A4 in association with high expression of vimentin and low expression of E-cadherin correlates with decreased OS [195]. Moreover, in vivo mouse model studies could demonstrate that the depletion of S100A4+ stroma cells, including mainly fibroblasts and macrophages, within the TME of HCC, reduced stemness of the tumour, and inflammation [196]. However, Li et al. presented evidence showing that S100A4 in cooperation with collagen I is involved in the development of fibrosis-associated HCC by upregulating stem cell marker genes, for example, Oct-4, Nanog, and SOX2, via RAGE-dependent $\beta$-catenin signalling [197]. Recently, S100A14 was introduced as a promising marker, as it was overexpressed in HCC tissue compared with healthy liver tissue and cirrhosis tissue, and therefore might be a sensitive assistant for diagnosis of HCC [198,199].

The expression of S100 proteins in oral squamous cell cancer (OSCC) remains controversial, as expression profiles vary from study to study, and further investigation is needed to identify reliable biomarkers among the S100 family members in this context [200]. Nevertheless, S100A14 seems to have tumour-suppressing properties in oral cancer, as overexpression of S100A14 in OSCC cell lines 
resulted in suppression of invasion, associated with the downregulation of MMP1 and MMP9, as well as decreased proliferation, correlating with upregulation of p21 and $\mathrm{G}_{1}$ cell cycle arrest $[201,202]$.

The evaluated expression of $S 100$ proteins could also be detected in malignant mesothelioma [203]. In this context, S100A4 was shown to be a promising biomarker, as it correlated with tumour progression, morphologic changes related to EMT, invasion, and metastasis [204]. However, more research is needed to validate the role of $\mathrm{S} 100$ family members in malignant mesothelioma.

Soluble factors originating from glioma cells have been linked to affecting the tolerance of microglia, which function as mediators of innate and adaptive immune responses. The activation of immunosuppressive signalling pathways such as STAT3 blocks the effector function of microglia [205208]. There is growing evidence that the RAGE ligand S100B is another factor that plays a role in glioma progression. Low levels of S100B expressed by gliomas triggered STAT3 and blocked microglia and also macrophage activation [209]. S100B may also encourage glioma growth by TAM chemoattraction and therefore, infiltration into gliomas through the upregulation of CCL2 [210]. In a high-throughput screening cell-based S100B promoter-driven luciferase reporter assay, duloxetine was identified to inhibit S100B and CCL2 production in a mouse glioma model. The inhibitor had the potential to modulate the immune-suppressive behaviour of TAMs [211]. Moreover, it has been revealed that high S100B levels correlate with poor prognosis in recurrent glioma patients [212].

\section{Targeting S100 Proteins for Cancer Therapy}

As it is now well established that S100 proteins are widely involved in carcinogenesis, invasion, and metastasis, a broad spectrum of novel therapeutic opportunities arises. There are several different strategies for targeting the $\mathrm{S} 100$ family members in cancer. While some inhibitors seem to be effective by inhibiting the transcription of S100 genes, others inhibit S100 protein activity by disturbing the interaction between S100 proteins and their targets. In addition, targeting covalent modifications, such as S-nitrosylation, S-glutathionylation, and phosphorylation, could be a promising strategy, as these modifications influence the function of S100 proteins [213]. In this review, S100 inhibitors are classified into small molecule inhibitors, neutralising antibodies, and microRNA (miRNA) mimics, and a summary is given in Table 1.

Table 1. Overview of potential S100 inhibitors.

\begin{tabular}{|c|c|c|c|c|}
\hline Inhibitor & S100 Target & Mechanism of Action & Current Status & References \\
\hline \multicolumn{5}{|c|}{ Small Molecule Inhibitors } \\
\hline Calcimycin & $\begin{array}{l}\text { Transcription of } \\
\text { S100A4 }\end{array}$ & $\begin{array}{l}\text { Inhibition of } \beta \text {-catenin expression, which } \\
\text { inhibits } W n t / \beta \text {-catenin signalling and } \\
\text { therefore expression of S100A4 }\end{array}$ & Pre-clinical & [214] \\
\hline Sulindac & $\begin{array}{l}\text { Transcription of } \\
\text { S100A4 }\end{array}$ & $\begin{array}{l}\text { Inhibition of } \beta \text {-catenin expression, which } \\
\text { inhibits Wnt } / \beta \text {-catenin signalling and } \\
\text { therefore expression of S100A4 }\end{array}$ & Pre-clinical & [215] \\
\hline Niclosamide & $\begin{array}{l}\text { Transcription of } \\
\text { S100A4 }\end{array}$ & $\begin{array}{l}\text { Inhibition of } \beta \text {-catenin/TCF complex } \\
\text { binding to the S100A4 promoter leading to } \\
\text { reduced expression of S100A4 }\end{array}$ & $\begin{array}{l}\text { Phase II for treatment of } \\
\text { CRC metastasised } \\
\text { patients }\end{array}$ & {$[216,217]$} \\
\hline $\begin{array}{l}\text { Trifluoperazine } \\
\text { (TFP) }\end{array}$ & S100A4 & $\begin{array}{l}\mathrm{Ca}^{2+}-\mathrm{S} 100 \mathrm{~A} 4 / \mathrm{TFP} \text { dimers form a } \\
\text { pentameric ring, disabling interaction } \\
\text { between S100A4 and myosinIIA }\end{array}$ & Pre-clinical & {$[218,219]$} \\
\hline 1,2,4-triazoles & S100A10 & $\begin{array}{l}\text { Competes with annexin A2 for the binding } \\
\text { to S100A10 }\end{array}$ & Pre-clinical & {$[224,225]$} \\
\hline Pentamidine & S100B & $\begin{array}{l}\text { Binds to S100B and inhibits interaction with } \\
\text { p53, therefore restoring p53 activity }\end{array}$ & $\begin{array}{l}\text { Phase II for treatment of } \\
\text { refractory melanoma }\end{array}$ & [226-228] \\
\hline $\begin{array}{l}\text { Cromolyn } \\
\text { 5-methyl cromolyn }\end{array}$ & S100P & $\begin{array}{c}\text { Binds to S100P and prevents interaction } \\
\text { with RAGE }\end{array}$ & Pre-clinical & [229-231] \\
\hline
\end{tabular}


Table 1. Cont.

\begin{tabular}{|c|c|c|c|c|}
\hline Inhibitor & S100 Target & Mechanism of Action & Current Status & References \\
\hline \multicolumn{5}{|l|}{ Antibodies } \\
\hline 6B12 & S100A4 & $\begin{array}{l}\text { Binds extracellular S100A4 and thereby acts } \\
\text { as an immunomodulating agent }\end{array}$ & Pre-clinical & {$[232,233]$} \\
\hline $5 \mathrm{C} 3$ & S100A4 & Binds to and neutralises S100A4 & Pre-clinical & [234] \\
\hline $6 \mathrm{~F} 5$ & S100A7 & $\begin{array}{l}\text { Binds to S100A7 and thereby blocks } \\
\text { S100A7/RAGE interaction }\end{array}$ & Pre-clinical & [235] \\
\hline $2 \mathrm{H} 8$ & S100P & $\begin{array}{l}\text { Binds S100P and therefore reduces tumour } \\
\text { growth and metastasis }\end{array}$ & Pre-clinical & [237] \\
\hline \multicolumn{5}{|l|}{ miRNA } \\
\hline miR-193a & S100A6 & $\begin{array}{l}\text { S100A6 silencing results in suppression of } \\
\text { proliferation, invasion, migration, and } \\
\text { angiogenesis within lung cancer models }\end{array}$ & Pre-clinical & [240] \\
\hline miR-26b-5p & S100A7 & $\begin{array}{l}\text { S100A7 silencing inhibits proliferation, } \\
\text { invasion, and migration of intrahepatic } \\
\text { cholangiocarcinoma cells }\end{array}$ & Pre-clinical & [241] \\
\hline miR-24 & S100A8 & $\begin{array}{l}\text { S100A8 silencing leads to decreased } \\
\text { proliferation and invasion of laryngeal } \\
\text { carcinoma cells and increases sensitivity of } \\
\text { endometrial carcinoma cells for paclitaxel }\end{array}$ & Pre-clinical & {$[242,243]$} \\
\hline
\end{tabular}

\subsection{Small Molecule Inhibitors}

Small molecule inhibitors are compounds $(<500 \mathrm{Da})$ able to penetrate tissue more effectively than macromolecules and are usually suitable for oral administration [245]. Although several small molecule inhibitors have been approved for cancer treatment, it is essential to further identify new compounds, to overcome drug resistance [246].

In this context, small molecule inhibitors were found which inhibit the transcription of S100 genes. The expression of S100A4, for example, is mediated by Wnt/ $\beta$-catenin signalling, a pathway which is highly involved in many cancer types, especially colon cancer. Therefore, inhibitors were introduced to inhibit the transcription of the S100A4 gene by interfering with the Wnt pathway [45]. Calcimycin, a calcium ionophore, and sulindac sulfide (sulindac), a nonsteroidal anti-inflammatory drug, inhibit the expression of $\beta$-catenin, leading to reduced levels of target genes, including S100A4. Treatment of mice with these inhibitors resulted in decreased tumour growth, reduced invasion, and fewer metastases of colon cancer at least partially due to lower levels of S100A4 [214,215]. Furthermore, the U.S. Food and Drug Administration (FDA)-approved anthelmintic drug niclosamide was identified to inhibit S100A4-induced metastasis formation of colon cancer, by preventing $\beta$-catenin/T-cell factor (TCF) complex formation and therefore transcription of S100A4 [216]. Niclosamide tablets are currently being studied in a phase II clinical trial for the treatment of metastasised CRC [217]. Although these inhibitors seem to be very effective in pre-clinical studies, it is vital to notice that they are not selective inhibitors of S100A4, for example, the inhibition of $\beta$-catenin also results in downregulation of cyclin D1 and the proto-oncogene c-Myc [214], which might cause unfavourable side effects [247].

Other small molecule inhibitors, therefore, follow the strategy of inhibiting the target interaction of S100 proteins. Trifluoperazine (TFP), a phenothiazine, for example, was introduced as an S100A4 inhibitor, as TFP and S100A4 form heterodimers and five dimers then arrange to a pentameric ring. This sequestering mechanism inhibits the interaction between S100A4 and myosin-IIA, indicating 
that TFP might influence cell motility $[218,219]$. Structure-based virtual inhibitor screening could also identify substituted 1,2,4-triazoles as potential S100A10 inhibitors, as it was demonstrated that 1,2,4-triazole competes with annexin A2 over the binding to S100A10 [224,225]. However, the effects of TFP and 1,2,4-triazoles in vitro and in vivo have yet to be demonstrated.

Furthermore, tasquinimod, a quinoline-3-carboxamide derivative, could be identified as an S100A9 inhibitor. Tasquinimod binds to S100A9 and therefore blocks the interaction with RAGE and TLR4, which influences the TME by modulating myeloid cell populations [220-222]. Recently, a phase III clinical trial was completed, investigating the effect of tasquinimod on patients with metastatic castration-resistant prostate cancer (mCRPC). This study showed that treatment with tasquinimod resulted in significantly longer radiologic progression-free survival compared with the placebo group (7.0 months vs. 4.4 months), but no influence on the OS was observed ( 24 months for placebo vs. 21.3 months for tasquinimod treatment) [223].

As previously described, the interaction of S100B and p53 is a promising target, especially in melanoma $[54,142,143]$. In this context, pentamidine, an antiprotozoal agent, was identified to bind to the p53 binding site of S100B, thereby inhibiting S100B/p53 interaction, allowing p53 to restore tumour-suppressing properties [226,227]. Pentamidine is currently being evaluated within a phase II clinical study for the treatment of refractory wild-type p53 melanoma [228].

Another noteworthy S100 inhibitor is the anti-allergy drug cromolyn. Cromolyn binds to S100P, thereby inhibiting interaction with RAGE, leading to decreased proliferation, invasion, and NF- $\mathrm{KB}$ activity in vitro and reduced tumour growth in vivo. Moreover, cromolyn increased gemcitabine sensitivity for pancreatic cancer models $[229,230]$. However, high concentrations of cromolyn were needed to achieve these effects. A more recent study showed that the analogue 5-methyl cromolyn is more efficient than cromolyn, and lower doses could induce similar reactions [231].

\subsection{Neutralising Antibodies}

Therapeutic antibodies have brought great benefit to cancer therapy, as they are more selective compared with conventional chemotherapeutics, and evolving technology has enabled the development of 30 FDA-approved monoclonal antibodies for cancer treatment so far $[248,249]$. The anti-cancer effect of these antibodies is either achieved by immune-mediating mechanisms or by neutralising important players of tumorigenic pathways $[250,251]$. The latter strategy seems to be an exciting approach to target S100 proteins.

As it was shown that S100A4 is highly involved in metastatic processes through influencing the TME, it is a favourable strategy to neutralise S100A4 activity. In this context, an anti-S100A4 antibody, named 6B12, showed immunomodulatory activity by binding S100A4 and thereby preventing T-cell attraction to the tumour side, which reduced metastasis in lung and breast cancer within experimental mouse models [232,233]. The anti-S100A4 antibody 5C3 could show similar effects as it terminated endothelial tumour growth, cell migration and angiogenesis in vitro and in vivo for pancreatic cancer and melanoma models. In addition, a synergistic effect between 5C3 and gemcitabine was observed [234].

Furthermore, a monoclonal antibody targeting extracellular S100A7 was designed. It could be demonstrated that this anti-S100A7 antibody, named 6F5, blocks S100A7/RAGE interaction, thereby inhibiting S100A7-mediated MMP9 activity, leading to decreased tumour growth, cell migration, and angiogenesis in a xenograft cancer model [235]. In terms of neutralising the DAMP molecules S100A8 and S100A9, monoclonal Ab45 was identified to be the most selective among ten anti-S100A8/S100A9 antibodies. In vitro, Ab45 could inhibit S100A8/S100A9-stimulated chemotaxis, and in vitro significantly reduced lung metastasis within a melanoma model [236]. The anti-S100P antibody $2 \mathrm{H} 8$ was introduced to inhibit S100P-induced proliferation of pancreatic cancer cells and blocked increased survival induced by S100P after gemcitabine treatment. Moreover, it was suggested that $2 \mathrm{H} 8$ is more effective than the small molecule inhibitor cromolyn, as cromolyn has a more significant 
impact on only tumour growth, while $2 \mathrm{H} 8$ reduced tumour growth and additionally inhibited liver metastasis in vivo [237].

However, the development of S100 antibodies for cancer therapy is at its very beginning, and examples of other therapeutic antibodies showed that limited clinical efficacy, for example, due to lacking tumour tissue penetration, immune reactions, and antibody resistance [252], is an issue which might need to be overcome in the later stages of this process.

\subsection{Micro RNA (miRNA) Mimics}

MiRNAs are short, non-coding nucleotides, which regulate gene expression on the post-transcriptional level by binding to their target mRNA and thereby either repress translation or tag the mRNA for degradation [253]. In recent years, new technology was established, which exploits this natural process of gene silencing by using miRNA mimics, chemically synthesised double-stranded RNAs, which act as mature miRNA once transfected into the cell [254].

Several miRNAs were introduced to target the expression of S100 proteins. Among them, two miRNAs, namely miR-187-3p and miR-149-3p, were found to downregulate S100A4 expression. The treatment of HCC in vitro and in vivo with miR-187-3p resulted in reduced metastasis and EMT, while miR-149-3p could inhibit invasion and migration of bladder cancer cells [238,239]. Furthermore, miR-193a suppressed proliferation, invasion, migration, and angiogenesis in vitro and in vivo within lung cancer models by silencing S100A6 [240].

The expression of S100A7 could be downregulated by miR-26b-5p, leading to decreased proliferation, migration, and invasion of intrahepatic cholangiocarcinoma in vitro [241]. Similar effects were observed for miR-24, a miRNA targeting S100A8, which inhibited proliferation and invasion of laryngeal carcinoma cells [242]. Besides, it was shown that S100A8-silencing by miR-24 reduced proliferation but enhanced sensitivity to paclitaxel of endometrial carcinoma cells [243]. Another interesting approach demonstrated that miR-6884-5p targets the expression of S100A16, which resulted in reduced proliferation, EMT, and invasion of gastric cancer cells in vitro [244].

The use of miRNA mimics, however, is a relatively new strategy for cancer therapy, and appropriate delivery systems need to be optimised to achieve effective treatment in the clinical context [255].

\section{Conclusions}

Research over the past decades could show that $\mathrm{S} 100$ proteins are highly involved in many different cellular processes and are essential players in pathophysiological mechanisms. S100 family members are widely expressed proteins in vertebrates, yet their way of functioning is strongly dependent on the tissue context. Several exciting and promising approaches were made to exploit the current knowledge and use S100 proteins as valuable associates in the context of cancer therapy. However, far more research is needed to broadly establish $\mathrm{S} 100$ proteins as reliable biomarkers and to identify and further optimise safe and efficient S100 therapeutics. Given initial promising results, a better understanding of S100 proteins and their properties will bring great benefit to novel clinical applications.

Author Contributions: C.A., A.-L.K., J.L. and D.H.-B. designed the study. C.A., A.-L.K., and M.W. performed the literature search. C.A., A.-L.K., M.W., and J.L. prepared the figures. C.A., A.-L.K., and S.v.K. wrote the manuscript. All authors contributed to the preparation of the manuscript. All authors have read and agreed to the published version of the manuscript.

Funding: This research was funded by a Deutsche Forschungsgemeinschaft (DFG) research grant (LE3556/1-1) awarded to J.L. S.v.K. was supported by a Max Eder grant (701125509) from the German Cancer Aid.

Conflicts of Interest: The authors declare no conflict of interest. 
Abbreviations

AD

ADC

AMP

ANT

ATP

Bcl-2

Bcl-xL

$\mathrm{Ca}^{2+}$

Cacy/SIP

CCL2

COP9

COPS5

COX2

$\mathrm{CP}$

CRC

CT

$\mathrm{Cu}^{2+}$

CXCL

DAMPs

ECG

ECM

EDC

EGF

EMMPRIN

EMT

ERK

$\mathrm{ER} \alpha$

FABP

FAK

FDA

$\mathrm{Fe}^{2+}$

HCC

HIF-1

IBD

ICI

IL-1 $\beta$

IFN- $\gamma$

Jab1

MAPK

MAP3K8

MCAM

MDR1

Mef2

MRP1

miRNA

MMP

$\mathrm{Mn}^{2+}$

mTOR

NCX1

$\mathrm{Ndr}$

NF-kB

NMIBC

NMIIA

Alzheimer's disease adenocarcinoma antimicrobial peptide adenine nucleotide translocator adenosine triphosphate namely B-cell lymphoma 2

B-cell lymphoma extra-large calcium ion calcyclin-binding protein/Siah-1-interacting protein chemokine ( $\mathrm{C}-\mathrm{C}$ motif) ligand 2 constitutive photomorphogenesis 9 COP9 constitutive photomorphogenic homolog subunit 5 cyclooxygenase-2

calprotectin

colorectal carcinoma

computerised tomography

copper ion

chemokine (C-X-C motif) ligand

danger-associated molecular patterns DAMPs

electrocardiogram

extracellular matrix

epidermal differentiation complex

epidermal growth factor

extracellular matrix metalloprotease inducer

epithelial-mesenchymal transition

extracellular signal-regulated kinase

in estrogen receptor $\alpha$

fatty acid-binding proteins

focal adhesion kinase

Food and Drug Administration

iron ion

hepatocellular carcinoma

hypoxia-inducible factor 1

inflammatory bowel disease

intracranial injuries

interleukin- $1 \beta$

interferon gamma

c-Jun activation domain-binding protein-1

mitogen-activated protein kinase

mitogen-activated protein kinase kinase kinase 8

melanoma cell adhesion molecule

multidrug resistance gene 1

myocyte enhancer factor-2

MDR-associated protein 1

micro RNA

metalloproteinase

manganese ion

mechanistic target of rapamycin

$\mathrm{Na}^{+} / \mathrm{Ca}^{2+}$ exchanger

nuclear dbf2-related

nuclear factor 'kappa-light-chain-enhancer' of activated B-cells

non-muscle-invasive bladder cancer

non-muscle myosin heavy chain IIA 
NOXA phorbol-12-myristate-13-acetate-induced protein 1

NSCLC non-small cell lung cancer

OS overall survival

OCSC ovarian cancer stem cells

PAD3 phytoalexin deficient 3

PDGF platelet-derived growth factor

PI3K phosphoinositide 3-kinase

PMCA1b plasma membrane $\mathrm{Ca}^{2+}$ transport ATPase

PUMA p53 upregulated modulator of apoptosis

RA rheumatoid arthritis

RAGE receptor for advanced glycation end products

ROS reactive oxygen species

RSK ribosomal S6 kinase

RyR2 ryanodine receptor 2

SCC squamous-cell carcinoma

SCLC small cell lung cancer

SERCA2a sarcoplasmic reticulum ATPase

Shh sonic hedgehog

SNC Scandinavian Neurotrauma Committee

STEMI ST-segment elevation myocardial infarction

TAMs tumour-associated macrophages

TBA traumatic brain injury

TCF T-cell factor

TLR4 Toll-like receptor 4

TME tumour microenvironment

$\mathrm{TNF} \alpha \quad$ tumour necrosis factor $\alpha$

tPA tissue plasminogen activator

TPL2 tumour progression locus 2

TRAF TNF receptor-associated factor 2

TRAIL tumour necrosis factor-related apoptosis-inducing ligand

TRPV6 transient receptor potential vanilloid 6

VEGF vascular endothelial growth factor

YAP yes-associated protein

$\mathrm{Zn}^{2+} \quad$ zinc ion 


\section{Appendix A}

Table A1. Summary of the S100 family members.

\begin{tabular}{|c|c|c|c|c|c|}
\hline Family Member & Expression & Regulation & Targets/Interaction & Function & References \\
\hline S100A1 & $\begin{array}{l}\text { Cardiomyocytes, skeletal } \\
\text { muscle cells, endothelial } \\
\text { cells, neurological cells }\end{array}$ & $\begin{array}{l}\text { Transcription factor binding sites for Nkx } \\
\text { 2.5, Mef2 and CEF }\end{array}$ & 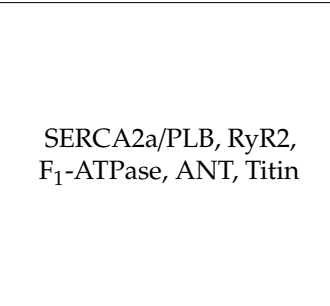 & $\begin{array}{c}\text { Modulates contractile performance in } \\
\text { cardiomyocytes: interaction with SERCA2a/PLB } \\
\text { and RyR2 improves systolic } \mathrm{Ca}^{2+} \text { release and } \\
\text { diastolic } \mathrm{Ca}^{2+} \text { uptake; binding to the PEVK } \\
\text { subdomain of titin results in improved } \\
\text { sarcomeric compliance } \\
\text { Mitochondrial metabolism: plays a role in } \\
\text { cardiac energy homeostasis by interacting with } \\
\mathrm{F}_{1} \text {-ATPase and ANT }\end{array}$ & {$[36,37,256]$} \\
\hline $\begin{array}{c}\text { S100A2 } \\
(\mathrm{S} 100 \mathrm{~L} ; \mathrm{CaN} 19)\end{array}$ & Epithelial tissue & $\begin{array}{l}\text { Transcriptional activation by p53 } \\
\text { EGF-induced transcription in } \\
\text { keratinocytes }\end{array}$ & p53, RAGE & $\begin{array}{l}\text { Tumour suppressor: calcium-dependent } \\
\text { activation of p53 }\end{array}$ & {$[51,78]$} \\
\hline $\begin{array}{l}\text { S100A3 } \\
(\mathrm{S} 100 \mathrm{E})\end{array}$ & Hair cuticular cells & $\begin{array}{l}\text { PAD3 induces the formation of a } \\
\text { homotetramer via citrullination }\end{array}$ & $\operatorname{RAR} \alpha$ & $\begin{array}{c}\text { Maintenance of the hair texture: } \\
\mathrm{Ca}^{2+} \text {-dependent epithelial barrier formation and } \\
\text { cuticular maturation }\end{array}$ & {$[22,257,258]$} \\
\hline $\begin{array}{l}\text { S100A4 } \\
\text { (metastasin; CAPL; } \\
\text { calvasculin) }\end{array}$ & $\begin{array}{l}\text { Fibroblasts, immune cells, } \\
\text { cancer cells }\end{array}$ & $\begin{array}{l}\text { Transcription is promoted by } \beta \text {-catenin } \\
\text { and growth factors }\end{array}$ & $\begin{array}{l}\text { actin, NMIIA, } \\
\text { tropomyosin, p53, p37, } \\
\text { MMP2, liprin- } \beta 1, \text { RAGE, } \\
\text { TLR4, EGFR, IL-10 } \\
\text { receptor, annexin II }\end{array}$ & $\begin{array}{l}\text { Cell migration: interaction with proteins of the } \\
\text { cytoskeleton and induces secretion of matrix } \\
\text { metalloproteinases (MMPs) } \\
\text { Cell growth and proliferation: activates NF-кB } \\
\text { and MAP kinases }\end{array}$ & {$[45,52,89]$} \\
\hline S100A5 & $\begin{array}{l}\text { olfactory bulb, brainstem, } \\
\text { spinal trigeminal tract }\end{array}$ & - & RAGE, NCXI & - & {$[34,259]$} \\
\hline $\begin{array}{l}\text { S100A6 } \\
\text { (Calcylin; Cacy; CABP; } \\
\text { PRA) }\end{array}$ & Fibroblasts, epithelial cells & $\begin{array}{l}\text { Extracellular by PDGF, EGF, retonic acid, } \\
\text { estrogen, gastrin } \\
\text { Under stress conditions: ischemia, } \\
\text { irradiation, oxidative stress } \\
\text { Intracellular: NF-kB activates } \\
\text { S100A6-promotor, while p53 indirectly } \\
\text { suppresses transcription }\end{array}$ & $\begin{array}{l}\text { caldesmon, calponin, } \\
\text { tropomyosin, kinesin light } \\
\text { chain, RAGE }\end{array}$ & $\begin{array}{l}\text { Control of cell cycle progression: involved in } \\
\text { ubiquitination of } \beta \text {-catenin } \\
\text { Regulation of microfilament dynamics: } \\
\text { interaction with proteins of the cytoskeleton } \\
\text { Neuronal apoptosis: binding to RAGE leads to } \\
\text { ROS-dependent activation of JNK, caspase-3, } \\
\text { and caspase-7 } \\
\text { As extracellular factor: involved in the release of } \\
\text { lactogen II, insulin, and histamine }\end{array}$ & {$[27,260]$} \\
\hline
\end{tabular}


Table A1. Cont.

\begin{tabular}{|c|c|c|c|c|c|}
\hline Family Member & Expression & Regulation & Targets/Interaction & Function & References \\
\hline $\begin{array}{l}\text { S100A7 } \\
\text { (Psoriasin) }\end{array}$ & Keratinocytes & $\begin{array}{l}\text { Secretion induced by disruptive stimuli } \\
\text { (e.g., UVB, irradiation, retonic acid, } \\
\text { infection with bacteria) } \\
\text { Upregulated by pro-inflammatory } \\
\text { cytokines (e.g., IL-1 } \alpha, \text { TNF } \alpha \text {, IL-17, IL-22) }\end{array}$ & RAGE, FABP, TGM & $\begin{array}{c}\text { Role as AMP: lyses bacteria (e.g., E. coli) } \\
\text { Inhibition of epidermal differentiation: } \\
\text { RAGE-dependent activation of NF-kB-signaling } \\
\text { results in upregulation of IL-6 } \\
\text { Inflammation: selective chemotactic for CD4 } \\
\text { lymphocytes and neutrophils }\end{array}$ & {$[28,42]$} \\
\hline $\begin{array}{c}\text { S100A8 } \\
\text { (Calgranulin A) }\end{array}$ & $\begin{array}{l}\text { Neutrophils, osteoclasts, } \\
\text { hypertrophic } \\
\text { chondrocytes, myeloid } \\
\text { dendric cells }\end{array}$ & $\begin{array}{l}\text { Induced by LPS, IL-10, TLR4, } \\
\text { glucocorticoids }\end{array}$ & Telomerase & $\begin{array}{l}\text { Inflammation: chemotactic for neutrophils, } \\
\text { protects from oxidation by scavenging oxidants, } \\
\text { acts as NO shuttle, thereby activating mast cells } \\
\text { Regulation of differentiation: binds and inhibits } \\
\text { telomerase, therefore promoting differentiation } \\
\text { in keratinocytes }\end{array}$ & {$[43,261]$} \\
\hline $\begin{array}{c}\text { S100A9 } \\
\text { (Calgranulin B) }\end{array}$ & $\begin{array}{c}\text { Neutrophil granulocytes, } \\
\text { monocytes }\end{array}$ & $\begin{array}{l}\text { Upregulated by glucocorticoids, } \\
\text { cytokines, and growth factors }\end{array}$ & RAGE, TLR4 & $\begin{array}{l}\text { Inflammation: } \mathrm{Zn}^{2+} \text {-dependent interaction with } \\
\text { RAGE and TLR4 leads to upregulation of } \\
\text { pro-inflammatory cytokines (e.g., TNF } \alpha \text { ) via } \\
\text { NF-KB signalling; acts as a chemoattractant and } \\
\text { is involved in differentiation of myeloid cells }\end{array}$ & {$[21,40,43]$} \\
\hline $\begin{array}{l}\text { S100A8/S100A9 } \\
\text { (Calprotectin) }\end{array}$ & $\begin{array}{c}\text { Neutrophils, monocytes, } \\
\text { macrophages, } \\
\text { inducible expression in } \\
\text { keratinocytes and } \\
\text { epithelial cells (e.g., under } \\
\text { inflammatory conditions) }\end{array}$ & $\begin{array}{l}\mathrm{TNF} \alpha \text {, IL-1 } \beta, \text { HIF- } 1 \text { stimulate expression } \\
\text { Secretion is } \mathrm{Ca}^{2+} \text {-dependent }\end{array}$ & RAGE, TLR4 & $\begin{array}{c}\text { Modulation of the cytoskeleton: interacts with } \\
\text { several proteins of the cytoskeleton (e.g., keratin } \\
\text { and F-actin) and promotes polymerisation of } \\
\text { microtubules } \\
\text { Protection against pathogens: S100A8/S100A9 } \\
\text { expressing epithelial cells are more resistant to } \\
\text { bacterial infection } \\
\text { Inflammation: RAGE- and TLR4-mediated } \\
\text { upregulation of pro-inflammatory cytokines } \\
\text { (e.g., IL-6 and IL-8) and adhesion proteins } \\
\text { (e.g., ICAM-1) }\end{array}$ & [29] \\
\hline $\begin{array}{l}\mathrm{S} 100 \mathrm{~A} 10 \\
(\mathrm{p} 11)\end{array}$ & $\begin{array}{c}\text { Endothelial cells, } \\
\text { macrophages, fibroblasts, } \\
\text { epithelial cells }\end{array}$ & $\begin{array}{l}\text { The expression can be induced by: } \\
\text { Sp1, IFN- } \gamma \text {, glucocorticoids, TGF } \beta, \text { EGF, } \\
\text { IL-1 } \beta \text {, thrombin, oncogenes (e.g., } \\
\text { PML-RAR } \alpha, \text { KRas) }\end{array}$ & $\begin{array}{l}\text { Annexin II, 5-HT1B } \\
\text { receptor, TRPV5, } \\
\text { TRPV6, TASK-1 }\end{array}$ & $\begin{array}{c}\text { Role as plasminogen receptor: regulates plasmin } \\
\text { production by forming a complex with annexin } \\
\text { II, which leads to fibrinolysis, activation of } \\
\text { MMPs, ECM degradation, stimulation of the } \\
\text { JAK1/TYK2 signalling pathway, and recruitment } \\
\text { of macrophages } \\
\text { Trafficking of plasma membrane proteins: } \\
\text { S100A10 interacts with the 5-HT1B } \\
\text { receptor, TRPV5, } \\
\text { TRPV6, and TASK-1 and participates in } \\
\text { their trafficking }\end{array}$ & {$[13,35]$} \\
\hline
\end{tabular}


Table A1. Cont.

\begin{tabular}{|c|c|c|c|c|c|}
\hline Family Member & Expression & Regulation & Targets/Interaction & Function & References \\
\hline $\begin{array}{c}\text { S100A11 } \\
\text { (S100C; calgizzarin) }\end{array}$ & $\begin{array}{l}\text { Chondrocytes, } \\
\text { keratinocytes, fibroblasts, } \\
\text { luteal cells }\end{array}$ & $\begin{array}{c}\text { TGF } \beta \text { and high extracellular } \mathrm{Ca}^{2+} \\
\text { concentrations stimulate expression and } \\
\text { activity }\end{array}$ & $\begin{array}{l}\text { RAGE, annexin I, } \\
\text { nucleolin }\end{array}$ & $\begin{array}{l}\text { Cell growth regulation: intracellular S100A11 } \\
\text { inhibits cell growth by binding to nucleolin, } \\
\text { which allows expression of p21, leading to } \\
\text { inhibition of DNA synthesis; extracellular } \\
\text { S100A11 promotes cell proliferation by } \\
\text { RAGE-mediated transcription of EGF } \\
\text { Interaction with RAGE: RAGE activates p38 } \\
\text { MAPK kinase, which increases type X collagen }\end{array}$ & {$[49,50]$} \\
\hline $\begin{array}{l}\text { S100A12 } \\
\text { (Calgranulin C; } \\
\text { EN-RAGE) }\end{array}$ & $\begin{array}{l}\text { Neutrophil granulocytes, } \\
\text { monocytes, macrophages, } \\
\text { early-stage differentiating } \\
\text { epithelial and dendric } \\
\text { cells }\end{array}$ & $\begin{array}{l}\text { Upregulated by TNF } \alpha \text { and LPS } \\
\text { Secretion in neutrophils involves ROS } \\
\text { and } \mathrm{K}^{+} \text {exchange }\end{array}$ & RAGE, TLR4, CacyBP/SIP & $\begin{array}{l}\text { Wnt signalling: binds to CacyBP/SIP and is part } \\
\text { of the ubiquitinylation complex } \\
\text { Inflammation: binding to TLR4 leads to } \\
\text { activation and migration of monocytes and } \\
\text { release of IL-1 } 1 \beta \text {, IL-6, and IL- } 8 \text {, RAGE-mediated } \\
\text { NF-kB and MAPK signalling induces secretion } \\
\text { of TNF } \alpha \text { and IL-1 } \beta \\
\text { Inhibition of pathogens: antifungal and } \\
\text { antibacterial activity via } \mathrm{Zn}^{2+} \text { sequestration }\end{array}$ & {$[41,262-264]$} \\
\hline S100A13 & $\begin{array}{c}\text { Leydig cells of testis, } \\
\text { follicle cells of thyroid, } \\
\text { smooth muscle, } \\
\text { endothelial and epithelial } \\
\text { cells }\end{array}$ & Induced by stress stimuli & RAGE, Syt1, SPHK1 & $\begin{array}{l}\text { Non-canonical secretion pathway: forms a } \\
\text { copper-dependent multiprotein complex with } \\
\text { Syt1 and SPHK and is thereby involved in the } \\
\text { non-classical stress-dependent release of FGF-1, } \\
\text { IL- } 1 \alpha \text {, and prothymosin- } \alpha\end{array}$ & {$[265-267]$} \\
\hline S100A14 & $\begin{array}{l}\text { High expression in } \\
\text { epithelial tissue, lower } \\
\text { expression in } \\
\text { mesenchymal tissue }\end{array}$ & Regulated by p53 & RAGE, p53 & $\begin{array}{c}\text { Interaction with RAGE: binding in lower } \\
\text { concentrations activates MAPK and NF-KB } \\
\text { signalling, leading to cell proliferation; binding } \\
\text { in high concentrations activates ROS production, } \\
\text { resulting in apoptosis }\end{array}$ & {$[46,53]$} \\
\hline $\begin{array}{c}\text { S100A15 } \\
\text { (S100A7A; koebnerisin) }\end{array}$ & $\begin{array}{l}\text { Dendric cells, endothelial } \\
\text { cells, vascular smooth } \\
\text { muscle cells, peripheral } \\
\text { nerves, keratinocytes }\end{array}$ & $\begin{array}{c}\text { Upregulated by } E \text {. coli through TLR4 } \\
\text { Transcription can be induced by IFN- } \gamma \text {, } \\
\text { IL- } 1 \beta, \text { TNF } \alpha \text {, and Th1 } \\
\text { Co-expression with S100A7 in } \\
\text { keratinocytes }\end{array}$ & GPCR & $\begin{array}{c}\text { Epidermal cell maturation: upregulated in } \\
\text { epidermal differentiation } \\
\text { Initial immune response: functions as an } \\
\text { antibacterial agent by reducing the survival of } E \text {. } \\
\text { coli and other strains } \\
\text { Inflammation: acts as a chemoattractant for } \\
\text { leucocytes via GPCR }\end{array}$ & {$[23,268]$} \\
\hline S100A16 & Astrocytes, adipocytes & $\mathrm{Ca}^{2+}$ influences nuclear import/export & p53 & $\begin{array}{l}\text { Overexpression in preadipocytes resulted in } \\
\text { increased proliferation and reduction in } \\
\text { insulin-stimulated glucose uptake and } \\
\text { Akt phosphorylation }\end{array}$ & {$[269,270]$} \\
\hline
\end{tabular}


Table A1. Cont.

\begin{tabular}{|c|c|c|c|c|c|}
\hline Family Member & Expression & Regulation & Targets/Interaction & Function & References \\
\hline S100B & $\begin{array}{c}\text { Astrocytes, } \\
\text { oligodendrocytes, } \\
\text { Schwann cells, ependymal } \\
\text { cells, melanocytes, } \\
\text { adipocytes, chondrocytes }\end{array}$ & $\begin{array}{l}\text { Secretion is regulated by IL-1 } \beta \text {, } \\
\text { extracellular } \mathrm{Ca}^{2+} \text { and } \mathrm{K}^{+}, \text {inhibitors of } \\
\text { gap junctions, antioxidants, } \\
\text { lipopolysaccharide, and apomorphine } \\
\text { p53 upregulates expression }\end{array}$ & $\begin{array}{c}\text { Extracellular: RAGE, } \\
\text { FGFR1 } \\
\text { Intracellular: Ndr kinase, } \\
\text { Src, Rac1, IQGAP1, p53 }\end{array}$ & $\begin{array}{l}\text { Cell migration: regulates F-actin-based } \\
\text { cytoskeleton via Src, IQGAP1, and Rac1 } \\
\text { Cell division: interaction with Ndr kinase leads } \\
\text { to the promotion of PI3K/Akt signalling } \\
\text { Role in tumour suppression: inhibits p53 } \\
\text { activity and reduces p53 } \\
\text { Proliferation: at higher concentrations, S100B } \\
\text { blocks RAGE and stimulates FGFR1, leading to } \\
\text { Ras/MEK/Erk-mediated proliferation; at low } \\
\text { concentrations, S100B additionally stimulates } \\
\text { RAGE-mediated p38 MAPK signalling, resulting } \\
\text { in activation of the mitogenic program }\end{array}$ & {$[47,65,271]$} \\
\hline $\begin{array}{c}\text { 100G } \\
(\mathrm{CaBP}-9 \mathrm{k})\end{array}$ & Epithelial cells & Vitamin D-dependent in the intestine & - & $\begin{array}{l}\text { Cellular } \mathrm{Ca}^{2+} \text { homeostasis: regulates } \\
\text { intracellular } \mathrm{Ca}^{2+} \text { levels and prevents toxic } \\
\text { concentrations }\end{array}$ & [33] \\
\hline S100P & $\begin{array}{l}\text { Epithelial cells, } \\
\text { leucocytes, }\end{array}$ & $\begin{array}{l}\text { Promoter has binding sites for SMAD, } \\
\text { STAT/CREB, and SP/KLF } \\
\text { During embryonic implantation: highly } \\
\text { expressed in the trophoblastic layer of } \\
\text { the embryo, and in the endometrium of } \\
\text { the uterine wall }\end{array}$ & $\begin{array}{c}\text { RAGE, IQGAP1, enzrin, } \\
\text { NMIIA }\end{array}$ & $\begin{array}{c}\text { Cell proliferation and survival: activates } \\
\text { RAGE-mediated NF-KB signalling; interaction } \\
\text { with IQGAP1 induces MAPK signalling cascade } \\
\text { Cell migration: promotes interaction with } \\
\text { F-actin (via enzrin) and reduces focal adhesion } \\
\text { sites (via NMIIA) }\end{array}$ & {$[48,272]$} \\
\hline S100Z & Leucocytes & - & - & - & [8] \\
\hline
\end{tabular}




\section{References}

1. Moore, B.W. A soluble protein characteristic of the nervous system. Biochem. Biophys. Res. Commun. 1965, 19, 739-744. [CrossRef]

2. Isobe, T.; Okuyama, T. The amino-acid sequence of S-100 protein (PAP I-b Protein) and Its relation to the calcium-binding proteins. Eur. J. Biochem. 1978, 89, 379-388. [CrossRef]

3. Isobe, T.; Okuyama, T. The Amino-Acid Sequence Of The $\alpha$ subunit in bovine brain S-100a protein. Eur. J. Biochem. 1981, 116, 79-86. [CrossRef]

4. Kozlyuk, N.; Monteith, A.J.; Garcia, V.; Damo, S.M.; Skaar, E.P.; Chazin, W.J. S100 proteins in the innate immune response to pathogens. Methods Mol. Biol. 2019, 1929, 275-290. [CrossRef]

5. Donato, R.; Cannon, B.R.; Sorci, G.; Riuzzi, F.; Hsu, K.; Weber, D.J.; Geczy, C.L. Functions of S100 proteins. Curr. Mol. Med. 2013, 13, 24-57. [CrossRef] [PubMed]

6. Gilston, B.A.; Skaar, E.P.; Chazin, W.J. Binding of transition metals to S100 proteins. Sci. China Life Sci. 2016, 59, 792-801. [CrossRef] [PubMed]

7. Kiss, B.; Ecsédi, P.; Simon, M.; Nyitray, L. Isolation and characterization of S100 protein-protein complexes. Methods Mol. Biol. 2019, 1929, 325-338. [CrossRef] [PubMed]

8. Calderone, V.; Fragai, M.; Luchinat, C. Reviewing the crystal structure of S100Z and other members of the S100 family: Implications in calcium-regulated quaternary structure. Methods Mol. Biol. 2019, 1929, 487-499. [CrossRef] [PubMed]

9. Donato, R. S100: A multigenic family of calcium-modulated proteins of the EF-hand type with intracellular and extracellular functional roles. Int. J. Biochem. Cell Biol. 2001, 33, 637-668. [CrossRef]

10. Spratt, D.E.; Barber, K.R.; Marlatt, N.M.; Ngo, V.; Macklin, J.A.; Xiao, Y.; Konermann, L.; Duennwald, M.L.; Shaw, G.S. A subset of calcium-binding S100 proteins show preferential heterodimerization. FEBS 2019, 286, 1859-1876. [CrossRef]

11. Melville, Z.; Aligholizadeh, E.; McKnight, L.E.; Weber, D.J.; Pozharski, E.; Weber, D.J. X-ray crystal structure of human calcium-bound S100A1. Acta Crystallogr. Sect. F Struct. Biol. Commun. 2017, 73, 215-221. [CrossRef] [PubMed]

12. Bhattacharya, S.; Bunick, C.G.; Chazin, W.J. Target selectivity in EF-hand calcium binding proteins. Biochim. Biophys. Acta 2004, 1742, 69-79. [CrossRef] [PubMed]

13. Saiki, Y.; Horii, A. Multiple functions of S100A10, an important cancer promoter. Pathol. Int. 2019, 69, 629-636. [CrossRef] [PubMed]

14. Holzinger, D.; Kessel, C.; Foell, D. S100 proteins in autoinflammation. In Textbook of Autoinflammation; Hashkes, P.J., Laxer, R.M., Simon, A., Eds.; Springer International Publishing: Cham, Switzerland, 2019; Volume 19, pp. 149-163.

15. Nakashige, T.G.; Zhang, B.; Krebs, C.; Nolan, E.M. Human calprotectin is an iron-sequestering host-defense protein. Nat. Chem. Biol. 2015, 11, 765-771. [CrossRef]

16. Corbin, B.D.; Seeley, E.H.; Raab, A.; Feldmann, J.; Miller, M.R.; Torres, V.J.; Anderson, K.L.; Dattilo, B.M.; Dunman, P.M.; Gerads, R.; et al. Metal chelation and inhibition of bacterial growth in tissue abscesses. Science 2008, 319, 962-965. [CrossRef]

17. Damoa, S.M.; Kehl-Fieb, T.E.; Sugitania, N.; Holta, M.E.; Rathia, S.; Murphya, W.J.; Zhangb, Y.; Betzc, C.; Hencha, L.; Fritzc, G.; et al. Molecular basis for manganese sequestration by calprotectin and roles in the innate immune response to invading bacterial pathogens. Proc. Natl. Acad. Sci. USA 2013, 110, 3841-3846. [CrossRef]

18. Marenholz, I.; Heizmann, C.W.; Fritz, G. S100 proteins in mouse and man: From evolution to function and pathology (including an update of the nomenclature). Biochem. Biophys. Res. Commun. 2004, 322, 1111-1122. [CrossRef]

19. Völkers, M.; Rohde, D.; Goodman, C.; Most, P. S100A1: A regulator of striated muscle sarcoplasmic reticulum Ca2+ handling, sarcomeric, and mitochondrial function. J. Biomed. Biotechnol. 2010, 2010, 178614. [CrossRef]

20. Leśniak, W. Epigenetic regulation of S100 protein expression. Clin. Epigenet. 2011, 2, 77-83. [CrossRef]

21. Källberg, E.; Vogl, T.; Liberg, D.; Olsson, A.; Bjo, P.; Wikstro, P.; Bergh, A.; Roth, J.; Ivars, F.; Leanderson, T. S100A9 interaction with tlr4 promotes tumor growth. PLoS ONE 2012, 7. [CrossRef] 
22. Ite, K.; Yonezawa, K.; Kitanishi, K.; Shimizu, N.; Unno, M. Optimal mutant model of human S100A3 protein citrullinated at arg51 by peptidylarginine deiminase type III and its solution structural properties. ACS Omega 2020, 5, 4032-4042. [CrossRef] [PubMed]

23. Wolf, R.; Ruzicka, T.; Yuspa, S.H. Novel S100A7 (psoriasin)/S100A15 (koebnerisin) subfamily: Highly homologous but distinct in regulation and function. Amino Acids 2011, 41, 789-796. [CrossRef] [PubMed]

24. Kypriotou, M.; Huber, M.; Hohl, D. The human epidermal differentiation complex: Cornified envelope precursors, S100 proteins and the 'fused genes' family. Exp. Dermatol. 2012, 21, 643-649. [CrossRef] [PubMed]

25. Choe, N.; Kwon, D.-H.; Shin, S.; Kim, Y.S.; Kim, Y.-K.; Kim, J.; Ahn, Y.; Eom, G.H.; Kook, H. The microRNA miR-124 inhibits vascular smooth muscle cell proliferation by targeting S100 calcium-binding protein A4 (S100A4). FEBS Lett. 2017, 591, 1041-1052. [CrossRef] [PubMed]

26. Wen, L.; Sun, J.; Chen, X.; Du, R. MiR-135b-dependent down-regulation of S100B promotes neural stem cell differentiation in a hypoxia/ischemia-induced cerebral palsy rat model. Am. J. Physiol. Cell Physiol. 2020. [CrossRef] [PubMed]

27. Donato, R.; Sorci, G.; Giambanco, I. S100A6 protein: Functional roles. Cell. Mol. Life Sci. CMLS 2017, 74, 2749-2760. [CrossRef]

28. Son, E.D.; Kim, H.-J.; Kim, K.H.; Bin, B.H.; Bae, I.-H.; Lim, K.-M.; Yu, S.J.; Cho, E.-G.; Lee, T.R. S100A7 (psoriasin) inhibits human epidermal differentiation by enhanced IL-6 secretion through IkB/NF- $\mathrm{kB}$ signalling. Exp. Dermatol. 2016, 25, 636-641. [CrossRef]

29. Pruenster, M.; Vogl, T.; Roth, J.; Sperandio, M. S100A8/A9: From basic science to clinical application. Pharmacol. Ther. 2016, 167, 120-131. [CrossRef]

30. Bertheloot, D.; Latz, E. HMGB1, IL-1 $\alpha$, IL-33 and S100 proteins: Dual-function alarmins. Cell. Mol. Immunol. 2017, 14, 43-64. [CrossRef]

31. Galluzzi, L.; Vitale, I.; Aaronson, S.A.; Abrams, J.M.; Adam, D.; Agostinis, P.; Alnemri, E.S.; Altucci, L.; Amelio, I.; Andrews, D.W.; et al. Molecular mechanisms of cell death: Recommendations of the nomenclature committee on cell death 2018. Cell Death Differ. 2018, 25, 486-541. [CrossRef]

32. Bagur, R.; Hajnóczky, G. Intracellular Ca2+ sensing: Its role in calcium homeostasis and signaling. Mol. Cell 2017, 66, 780-788. [CrossRef] [PubMed]

33. Hong, E.-J.; Jeung, E.-B. Biological significance of calbindin-D9k within duodenal epithelium. Int. J. Mol. Sci. 2013, 14, 23330-23340. [CrossRef] [PubMed]

34. Wheeler, L.C.; Anderson, J.A.; Morrison, A.J.; Wong, C.E.; Harms, M.J. Conservation of specificity in two low-specificity proteins. Biochemistry 2018, 57, 684-695. [CrossRef] [PubMed]

35. Madureira, P.A.; O'Connell, P.A.; Surette, A.P.; Miller, V.A.; Waisman, D.M. The biochemistry and regulation of S100A10: A multifunctional plasminogen receptor involved in oncogenesis. J. Biomed. Biotechnol. 2012, 2012, 353687. [CrossRef]

36. Ritterhoff, J.; Most, P. Targeting S100A1 in heart failure. Gene Ther. 2012, 19, 613-621. [CrossRef]

37. Rohde, D.; Ritterhoff, J.; Voelkers, M.; Katus, H.A.; Parker, T.G.; Most, P. S100A1: A multifaceted therapeutic target in cardiovascular disease. J. Cardiovasc. Transl. Res. 2010, 3, 525-537. [CrossRef]

38. Kessel, C.; Holzinger, D.; Foell, D. Phagocyte-derived S100 proteins in autoinflammation: Putative role in pathogenesis and usefulness as biomarkers. Clin. Immunol. 2013, 147, 229-241. [CrossRef]

39. Timmermans, K.; Kox, M.; Scheffer, G.J.; Pickkers, P. Danger in the intensive care unit: Damps in critically ill patients. Shock 2016, 45, 108-116. [CrossRef]

40. Markowitz, J.; Carson, W.E. Review of S100A9 biology and its role in cancer. Biochim. Biophys. Acta 2013, 1835, 100-109. [CrossRef]

41. Carvalho, A.; Lu, J.; Francis, J.D.; Moore, R.E.; Haley, K.P.; Doster, R.S.; Townsend, S.D.; Johnson, J.G.; Damo, S.M.; Gaddy, J.A. S100A12 in digestive diseases and health: A scoping review. Gastroenterol. Res. Pract. 2020, 2020, 2868373. [CrossRef]

42. Krop, I.; März, A.; Carlsson, H.; Li, X.; Bloushtain-Qimron, N.; Hu, M.; Gelman, R.; Sabel, M.S.; Schnitt, S.; Ramaswamy, S.; et al. A putative role for psoriasin in breast tumor progression. Cancer Res. 2005, 65, 11326-11334. [CrossRef]

43. Goyette, J.; Geczy, C.L. Inflammation-associated S100 proteins: New mechanisms that regulate function. Amino Acids 2011, 41, 821-842. [CrossRef] [PubMed] 
44. Bianchi, R.; Kastrisianaki, E.; Giambanco, I.; Donato, R. S100B protein stimulates microglia migration via RAGE-dependent up-regulation of chemokine expression and release. J. Biol. Chem. 2011, 286, 7214-7226. [CrossRef] [PubMed]

45. Dahlmann, M.; Kobelt, D.; Walther, W.; Mudduluru, G.; Stein, U. S100A4 in cancer metastasis: Wnt signaling-driven interventions for metastasis restriction. Cancers 2016, 8, 59. [CrossRef] [PubMed]

46. Jin, Q.e.; Chen, H.; Luo, A.; Ding, F.; Liu, Z. S100A14 stimulates cell proliferation and induces cell apoptosis at different concentrations via receptor for advanced glycation end products (RAGE). PLoS ONE 2011, 6, e19375. [CrossRef]

47. Riuzzi, F.; Sorci, G.; Beccafico, S.; Donato, R. S100B engages RAGE or bFGF/FGFR1 in myoblasts depending on its own concentration and myoblast density. Implications for muscle regeneration. PLOS ONE 2012, 7. [CrossRef]

48. Prica, F.; Radon, T.; Cheng, Y.; Crnogorac-Jurcevic, T. The life and works of S100P-from conception to cancer. Am. J. Cancer Res. 2016, 6, 562-576.

49. Sakaguchi, M.; Huh, N.-H. S100A11, a dual growth regulator of epidermal keratinocytes. Amino Acids 2011, 41, 797-807. [CrossRef]

50. He, H.; Li, J.; Weng, S.; Li, M.; Yu, Y. S100A11: Diverse function and pathology corresponding to different target proteins. Cell Biochem. Biophys. 2009, 55, 117-126. [CrossRef]

51. Pan, S.-C.; Li, C.-Y.; Kuo, C.-Y.; Kuo, Y.-Z.; Fang, W.-Y.; Huang, Y.-H.; Hsieh, T.-C.; Kao, H.-Y.; Kuo, Y.; Kang, Y.-R.; et al. The p53-S100A2 positive feedback loop negatively regulates epithelialization in cutaneous wound healing. Sci. Rep. 2018, 8, 5458. [CrossRef]

52. Boye, K.; Maelandsmo, G.M. S100A4 and metastasis: A small actor playing many roles. Am. J. Pathol. 2010, 176, 528-535. [CrossRef] [PubMed]

53. Basnet, S.; Sharma, S.; Costea, D.E.; Sapkota, D. Expression profile and functional role of S100A14 in human cancer. Oncotarget 2019, 10, 2996-3012. [CrossRef] [PubMed]

54. Lin, J.; Yang, Q.; Wilder, P.T.; Carrier, F.; Weber, D.J. The calcium-binding protein S100B down-regulates p53 and apoptosis in malignant melanoma. J. Biol. Chem. 2010, 285, 27487-27498. [CrossRef] [PubMed]

55. Aubrey, B.J.; Kelly, G.L.; Janic, A.; Herold, M.J.; Strasser, A. How does p53 induce apoptosis and how does this relate to p53-mediated tumour suppression? Cell Death Differ. 2018, 25, 104-113. [CrossRef] [PubMed]

56. Austermann, J.; Spiekermann, C.; Roth, J. S100 proteins in rheumatic diseases. Nat. Rev. Rheumatol. 2018, 14, 528-541. [CrossRef] [PubMed]

57. Perera, C.; McNeil, H.P.; Geczy, C.L. S100 calgranulins in inflammatory arthritis. Immunol. Cell Biol. 2010, 88 , 41-49. [CrossRef] [PubMed]

58. Friedman, B.; Cronstein, B. Methotrexate mechanism in treatment of rheumatoid arthritis. Jt. Bone Spine 2019, 86, 301-307. [CrossRef]

59. Boschetti, G.; Garnero, P.; Moussata, D.; Cuerq, C.; Préaudat, C.; Duclaux-Loras, R.; Mialon, A.; Drai, J.; Flourié, B.; Nancey, S. Accuracies of serum and fecal S100 proteins (calprotectin and calgranulin C) to predict the response to TNF antagonists in patients with Crohn's disease. Inflamm. Bowel Dis. 2015, 21, 331-336. [CrossRef]

60. Foell, D.; Frosch, M.; Sorg, C.; Roth, J. Phagocyte-specific calcium-binding S100 proteins as clinical laboratory markers of inflammation. Clin. Chim. Acta 2004, 344, 37-51. [CrossRef]

61. Heizmann, C.W. S100 proteins: Diagnostic and prognostic biomarkers in laboratory medicine. Biochim. Biophys. Acta 2019, 1866, 1197-1206. [CrossRef]

62. Undén, J.; Ingebrigtsen, T.; Romner, B. Scandinavian guidelines for initial management of minimal, mild and moderate head injuries in adults: An evidence and consensus-based update. BMC Med. 2013, 11. [CrossRef] [PubMed]

63. Jones, C.M.C.; Harmon, C.; McCann, M.; Gunyan, H.; Bazarian, J.J. S100B outperforms clinical decision rules for the identification of intracranial injury on head CT scan after mild traumatic brain injury. Brain Inj. 2020, 34, 407-414. [CrossRef]

64. Vedin, T.; Svensson, S.; Edelhamre, M.; Karlsson, M.; Bergenheim, M.; Larsson, P.-A. Management of mild traumatic brain injury-trauma energy level and medical history as possible predictors for intracranial hemorrhage. Eur. J. Trauma Emerg. Surg. 2019, 45, 901-907. [CrossRef] [PubMed] 
65. Michetti, F.; D’Ambrosi, N.; Toesca, A.; Puglisi, M.A.; Serrano, A.; Marchese, E.; Corvino, V.; Geloso, M.C. The S100B story: From biomarker to active factor in neural injury. J. Neurochem. 2019, 148, 168-187. [CrossRef] [PubMed]

66. Cristóvão, J.S.; Gomes, C.M. S100 proteins in alzheimer's disease. Front. Neurosci. 2019, 13, 463. [CrossRef] [PubMed]

67. Fan, L.; Liu, B.; Guo, R.; Luo, J.; Li, H.; Li, Z.; Xu, W. Elevated plasma S100A1 level is a risk factor for ST-segment elevation myocardial infarction and associated with post-infarction cardiac function. Int. J. Med. Sci. 2019, 16, 1171-1179. [CrossRef] [PubMed]

68. Heizmann, C.W. Ca2+-Binding proteins of the EF-hand superfamily: Diagnostic and prognostic biomarkers and novel therapeutic targets. Methods Mol. Biol. 2019, 1929, 157-186. [CrossRef] [PubMed]

69. Rohde, D.; Brinks, H.; Ritterhoff, J.; Qui, G.; Ren, S.; Most, P. S100A1 gene therapy for heart failure: A novel strategy on the verge of clinical trials. J. Mol. Cell. Cardiol. 2011, 50, 777-784. [CrossRef]

70. Gaynor, R.; Irie, R.; Morton, D.; Herschman, H.R. S100 protein is present in cultured human malignant melanomas. Nature 1980, 286, 400-401. [CrossRef]

71. Gaynor, R.; Herschman, H.R.; Irie, R.; Jones, P.; Morton, D.; Cochran, A. S100 protein: A marker for human malignant melanomas? Lancet 1981, 1, 869-871. [CrossRef]

72. Takashi, M.; Haimoto, H.; Murase, T.; Mitsuya, H.; Kato, K. An immunochemical and immunohistochemical study of S100 protein in renal cell carcinoma. Cancer 1988, 61, 889-895. [CrossRef]

73. Gillett, C.E.; Bobrow, L.G.; Millis, R.R. S100 protein in human mammary tissue-immunoreactivity in breast carcinoma, including Paget's disease of the nipple, and value as a marker of myoepithelial cells. J. Pathol. 1990, 160, 19-24. [CrossRef] [PubMed]

74. Kuźnicki, J.; Filipek, A.; Hunziker, P.E.; Huber, S.; Heizmann, C.W. Calcium-binding protein from mouse Ehrlich ascites-tumour cells is homologous to human calcyclin. Biochem. J. 1989, 263, 951-956. [CrossRef] [PubMed]

75. Kimura, T.; Budka, H. Glial fibrillary acidic protein and S-100 protein in human hepatic encephalopathy: Immunocytochemical demonstration of dissociation of two glia-associated proteins. Acta Neuropathol. 1986, 70, 17-21. [CrossRef]

76. Bresnick, A.R.; Weber, D.J.; Zimmer, D.B. S100 proteins in cancer. Nat. Rev. Cancer 2015, 15, 96-109. [CrossRef]

77. Hua, X.; Zhang, H.; Jia, J.; Chen, S.; Sun, Y.; Zhu, X. Roles of S100 family members in drug resistance in tumors: Status and prospects. Biomed. Pharmacother. 2020, 127, 110156. [CrossRef]

78. Wolf, S.; Haase-Kohn, C.; Pietzsch, J. S100A2 in cancerogenesis: A friend or a foe? Amino Acids 2011, 41, 849-861. [CrossRef]

79. Bray, F.; Ferlay, J.; Soerjomataram, I.; Siegel, R.L.; Torre, L.A.; Jemal, A. Global cancer statistics 2018: GLOBOCAN estimates of incidence and mortality worldwide for 36 cancers in 185 countries. CA Cancer J. Clin. 2018, 68, 394-424. [CrossRef]

80. Yates, L.R.; Knappskog, S.; Wedge, D.; Farmery, J.H.R.; Gonzalez, S.; Martincorena, I.; Alexandrov, L.B.; van Loo, P.; Haugland, H.K.; Lilleng, P.K.; et al. Genomic evolution of breast cancer metastasis and relapse. Cancer Cell 2017, 32, 169-184.e167. [CrossRef]

81. Li, F.; Men, X.; Zhang, W. S100 protein in breast tumor. Indian J. Cancer 2014, 51 (Suppl. S3), 67-71. [CrossRef]

82. Cancemi, P.; Bivona, S.; Pucci-Minafra, I.; Buttacavoli, M.; Di Cara, G.; Albanese, N.N.; Feo, S. A multiomics analysis of S100 protein family in breast cancer. Oncotarget 2018, 9, 29064-29081. [CrossRef] [PubMed]

83. Yen, M.C.; Huang, Y.C.; Kan, J.Y.; Kuo, P.L.; Hou, M.F.; Hsu, Y.L. S100B expression in breast cancer as a predictive marker for cancer metastasis. Int. J. Oncol. 2018, 52, 433-440. [CrossRef] [PubMed]

84. Zhang, S.; Wang, Z.; Liu, W.; Lei, R.; Shan, J.; Li, L.; Wang, X. Distinct prognostic values of S100 mRNA expression in breast cancer. Sci. Rep. 2017, 7, 39786. [CrossRef] [PubMed]

85. Zhong, J.M.; Li, J.; Kang, A.D.; Huang, S.Q.; Liu, W.B.; Zhang, Y.; Liu, Z.H.; Zeng, L. Protein S100-A8: A potential metastasis-associated protein for breast cancer determined via iTRAQ quantitative proteomic and clinicopathological analysis. Oncol. Lett. 2018, 15, 5285-5293. [CrossRef]

86. Charmsaz, S.; Hughes, É.; Bane, F.T.; Tibbitts, P.; McIlroy, M.; Byrne, C.; Cocchiglia, S.; McBryan, J.; Hennessy, B.T.; Dwyer, R.M.; et al. S100 $\beta$ as a serum marker in endocrine resistant breast cancer. BMC Med. 2017, 15, 79. [CrossRef] 
87. Darlix, A.; Lamy, P.-J.; Lopez-Crapez, E.; Braccini, A.L.; Firmin, N.; Romieu, G.; Thezenas, S.; Jacot, W. Serum HER2 extra-cellular domain, S100ß and CA 15-3 levels are independent prognostic factors in metastatic breast cancer patients. BMC Cancer 2016, 16, 428. [CrossRef]

88. McIlroy, M.; McCartan, D.; Early, S.; Gaora, P.Ó.; Pennington, S.; Hill, A.D.K.; Young, L.S. Interaction of developmental transcription factor HOX11 with steroid receptor coactivator SRC-1 mediates resistance to endocrine therapy in breast cancer. Cancer Res. 2010. [CrossRef]

89. Fei, F.; Qu, J.; Zhang, M.; Li, Y.; Zhang, S. S100A4 in cancer progression and metastasis: A systematic review. Oncotarget 2017, 8, 73219-73239. [CrossRef]

90. Jenkinson, S.R.; Barraclough, R.; West, C.R.; Rudland, P.S. S100A4 regulates cell motility and invasion in an in vitro model for breast cancer metastasis. Br. J. Cancer 2004, 90, 253-262. [CrossRef]

91. Barraclough, R.; Rudland, P.S. The S-100-related calcium-binding protein, p9Ka, and metastasis in rodent and human mammary cells. Eur. J. Cancer 1994, 30a, 1570-1576. [CrossRef]

92. Li, Z.H.; Dulyaninova, N.G.; House, R.P.; Almo, S.C.; Bresnick, A.R. S100A4 regulates macrophage chemotaxis. Mol. Biol. Cell 2010, 21, 2598-2610. [CrossRef] [PubMed]

93. Chen, P.S.; Wang, M.Y.; Wu, S.N.; Su, J.L.; Hong, C.C.; Chuang, S.E.; Chen, M.W.; Hua, K.T.; Wu, Y.L.; Cha, S.T.; et al. CTGF enhances the motility of breast cancer cells via an integrin-alphavbeta3-ERK1/2-dependent S100A4-upregulated pathway. J. Cell Sci. 2007, 120, 2053-2065. [CrossRef] [PubMed]

94. Wang, G.; Zhang, S.; Fernig, D.G.; Martin-Fernandez, M.; Rudland, P.S.; Barraclough, R. Mutually antagonistic actions of S100A4 and S100A1 on normal and metastatic phenotypes. Oncogene 2005, 24, 1445-1454. [CrossRef] [PubMed]

95. Xu, H.; Li, M.; Zhou, Y.; Wang, F.; Li, X.; Wang, L.; Fan, Q. S100A4 participates in epithelial-mesenchymal transition in breast cancer via targeting MMP2. Tumour Biol. 2016, 37, 2925-2932. [CrossRef] [PubMed]

96. Cabezón, T.; Celis, J.E.; Skibshøj, I.; Klingelhöfer, J.; Grigorian, M.; Gromov, P.; Rank, F.; Myklebust, J.H.; Maelandsmo, G.M.; Lukanidin, E.; et al. Expression of S100A4 by a variety of cell types present in the tumor microenvironment of human breast cancer. Int. J. Cancer 2007, 121, 1433-1444. [CrossRef]

97. Prasmickaite, L.; Tenstad, E.M.; Pettersen, S.; Jabeen, S.; Egeland, E.V.; Nord, S.; Pandya, A.; Haugen, M.H.; Kristensen, V.N.; Børresen-Dale, A.-L.; et al. Basal-like breast cancer engages tumor-supportive macrophages via secreted factors induced by extracellular S100A4. Mol. Oncol. 2018, 12, 1540-1558. [CrossRef]

98. Wang, N.; Ma, Q.; Wang, Y.; Ma, G.; Zhai, H. CacyBP/SIP expression is involved in the clinical progression of breast cancer. World J. Surg. 2010, 34, 2545-2552. [CrossRef]

99. Topolska-Woś, A.M.; Chazin, W.J.; Filipek, A. CacyBP/SIP—Structure and variety of functions. Biochim. Biophys. Acta 2016, 1860, 79-85. [CrossRef]

100. Leong, S.; Christopherson, R.I.; Baxter, R.C. Profiling of Apoptotic changes in human breast cancer cells using seldi-tof mass spectrometry. Cell. Physiol. Biochem. 2007, 20, 579-590. [CrossRef]

101. Nasser, M.W.; Wani, N.A.; Ahirwar, D.K.; Powell, C.A.; Ravi, J.; Elbaz, M.; Zhao, H.; Padilla, L.; Zhang, X.; Shilo, K.; et al. RAGE mediates S100A7-induced breast cancer growth and metastasis by modulating the tumor microenvironment. Cancer Res. 2015, 75, 974-985. [CrossRef]

102. Liu, H.; Wang, L.; Wang, X.; Cao, Z.; Yang, Q.; Zhang, K. S100A7 enhances invasion of human breast cancer MDA-MB-468 cells through activation of nuclear factor-kB signaling. World J. Surg. Oncol. 2013, 11. [CrossRef] [PubMed]

103. Nasser, M.W.; Qamri, Z.; Deol, Y.S.; Ravi, J.; Powell, C.A.; Trikha, P.; Schwendener, R.A.; Bai, X.-F.; Shilo, K.; Zou, X.; et al. S100A7 enhances mammary tumorigenesis through upregulation of inflammatory pathways. Cancer Res. 2012, 72, 604-615. [CrossRef] [PubMed]

104. Emberley, E.D.; Murphy, L.C.; Watson, P.H. S100A7 and the progression of breast cancer. Breast Cancer Res. 2004, 6, 153-159. [CrossRef] [PubMed]

105. Yin, C.; Li, H.; Zhang, B.; Liu, Y.; Lu, G.; Lu, S.; Sun, L.; Qi, Y.; Li, X.; Chen, W. RAGE-binding S100A8/A9 promotes the migration and invasion of human breast cancer cells through actin polymerization and epithelial-mesenchymal transition. Breast Cancer Res. Treat. 2013, 142, 297-309. [CrossRef]

106. Cassim, S.; Chepulis, L.; Keenan, R.; Kidd, J.; Firth, M.; Lawrenson, R. Patient and carer perceived barriers to early presentation and diagnosis of lung cancer: A systematic review. BMC Cancer 2019, 19, 25. [CrossRef]

107. Huang, C.-Y.; Ju, D.-T.; Chang, C.-F.; Muralidhar Reddy, P.; Velmurugan, B.K. A review on the effects of current chemotherapy drugs and natural agents in treating non-small cell lung cancer. Biomedicine 2017, 7, 23. [CrossRef] 
108. Khanmohammadi, A.; Aghaie, A.; Vahedi, E.; Qazvini, A.; Ghanei, M.; Afkhami, A.; Hajian, A.; Bagheri, H. Electrochemical biosensors for the detection of lung cancer biomarkers: A review. Talanta 2020, 206, 120251. [CrossRef]

109. Liu, Y.; Cui, J.; Tang, Y.-L.; Huang, L.; Zhou, C.-Y.; Xu, J.-X. Prognostic roles of mRNA expression of S100 in non-small-cell lung cancer. BioMed Res. Int. 2018, 2018, 9815806. [CrossRef]

110. Wang, T.; Huo, X.; Chong, Z.; Khan, H.; Liu, R. A review of S100 protein family in lung cancer. Clin. Chim. Acta 2018, 476, 54-59. [CrossRef]

111. Feng, G.; Xu, X.-C.; Youssef, E.M.; Lotan, R. Diminished expression of S100A2, a putative tumor suppressor, at early stage of human lung carcinogenesis. Cancer Res. 2001, 61, 7999-8004.

112. Heighway, J.; Knapp, T.; Boyce, L.; Brennand, S.; Field, J.K.; Betticher, D.C.; Ratschiller, D.; Gugger, M.; Donovan, M.; Lasek, A.; et al. Expression profiling of primary non-small cell lung cancer for target identification. Oncogene 2002, 21, 7749-7763. [CrossRef] [PubMed]

113. Bulk, E.; Sargin, B.; Krug, U.; Hascher, A.; Jun, Y.; Knop, M.; Kerkhoff, C.; Gerke, V.; Liersch, R.; Mesters, R.M.; et al. S100A2 induces metastasis in non-small cell lung cancer. Clin. Cancer Res. 2009, 15, 22-29. [CrossRef] [PubMed]

114. Hountis, P.; Matthaios, D.; Froudarakis, M.; Bouros, D.; Kakolyris, S. S100A2 protein and non-small cell lung cancer. The dual role concept. Tumour Biol. 2014, 35, 7327-7333. [CrossRef] [PubMed]

115. Mishra, S.K.; Siddique, H.R.; Saleem, M. S100A4 calcium-binding protein is key player in tumor progression and metastasis: Preclinical and clinical evidence. Cancer Metastasis Rev. 2012, 31, 163-172. [CrossRef] [PubMed]

116. Chen, N.; Sato, D.; Saiki, Y.; Sunamura, M.; Fukushige, S.; Horii, A. S100A4 is frequently overexpressed in lung cancer cells and promotes cell growth and cell motility. Biochem. Biophys. Res. Commun. 2014, 447, 459-464. [CrossRef]

117. Stewart, R.L.; Carpenter, B.L.; West, D.S.; Knifley, T.; Liu, L.; Wang, C.; Weiss, H.L.; Gal, T.S.; Durbin, E.B.; Arnold, S.M.; et al. S100A4 drives non-small cell lung cancer invasion, associates with poor prognosis, and is effectively targeted by the FDAapproved anti-helminthic agent niclosamide. Oncotarget 2016, 7, 34630-34642. [CrossRef]

118. Hou, S.; Tian, T.; Qi, D.; Sun, K.; Yuan, Q.; Wang, Z.; Qin, Z.; Wu, Z.; Chen, Z.; Zhang, J. S100A4 promotes lung tumor development through $\beta$-catenin pathway-mediated autophagy inhibition. Cell Death Dis. 2018, 9, 277. [CrossRef]

119. Liu, G.; Wu, Q.; Liu, G.; Song, X.; Zhang, J. Knockdown of S100A7 reduces lung squamous cell carcinoma cell growth in vitro and in vivo. Int. J. Clin. Exp. Pathol. 2014, 7, 8279-8289.

120. Wang, R.; Li, Y.; Hu, E.; Kong, F.; Wang, J.; Liu, J.; Shao, Q.; Hao, Y.; He, D.; Xiao, X. S100A7 promotes lung adenocarcinoma to squamous carcinoma transdifferentiation, and its expression is differentially regulated by the Hippo-YAP pathway in lung cancer cells. Oncotarget 2017, 8, 24804-24814. [CrossRef]

121. Choi, H.; Puvenna, V.; Brennan, C.; Mahmoud, S.; Wang, X.-F.; Phillips, M.; Janigro, D.; Mazzone, P. S100B and $\mathrm{S100B}$ autoantibody as biomarkers for early detection of brain metastases in lung cancer. Transl. Lung Cancer Res. 2016, 5, 413-419. [CrossRef]

122. Pang, X.; Min, J.; Liu, L.; Liu, Y.; Ma, N.; Zhang, H. S100B protein as a possible participant in the brain metastasis of NSCLC. Med. Oncol. 2012, 29, 2626-2632. [CrossRef] [PubMed]

123. Jiang, W.; Jia, Q.; Liu, L.; Zhao, X.; Tan, A.; Ma, N.; Zhang, H. S100B promotes the proliferation, migration and invasion of specific brain metastatic lung adenocarcinoma cell line. Cell Biochem. Funct. 2011, 29, 582-588. [CrossRef] [PubMed]

124. Domingues, B.; Lopes, J.M.; Soares, P.; Pópulo, H. Melanoma treatment in review. ImmunoTargets Ther. 2018, 7, 35-49. [CrossRef]

125. Deeks, E.D. Pembrolizumab: A review in advanced melanoma. Drugs 2016, 76, 375-386. [CrossRef] [PubMed]

126. Xiong, T.-F.; Pan, F.-Q.; Li, D. Expression and clinical significance of S100 family genes in patients with melanoma. Melanoma Res. 2019, 29, 23-29. [CrossRef]

127. Herwig, N.; Belter, B.; Wolf, S.; Haase-Kohn, C.; Pietzsch, J. Interaction of extracellular S100A4 with RAGE prompts prometastatic activation of A375 melanoma cells. J. Cell. Mol. Med. 2016, 20, 825-835. [CrossRef]

128. Herwig, N.; Belter, B.; Pietzsch, J. Extracellular S100A4 affects endothelial cell integrity and stimulates transmigration of A375 melanoma cells. Biochem. Biophys. Res. Commun. 2016, 477, 963-969. [CrossRef] 
129. Haase-Kohn, C.; Wolf, S.; Lenk, J.; Pietzsch, J. Copper-mediated cross-linking of S100A4, but not of S100A2, results in proinflammatory effects in melanoma cells. Biochem. Biophys. Res. Commun. 2011, 413, 494-498. [CrossRef]

130. Bettum, I.J.; Vasiliauskaite, K.; Nygaard, V.; Clancy, T.; Pettersen, S.J.; Tenstad, E.; Mælandsmo, G.M.; Prasmickaite, L. Metastasis-associated protein S100A4 induces a network of inflammatory cytokines that activate stromal cells to acquire pro-tumorigenic properties. Cancer Lett. 2014, 344, 28-39. [CrossRef]

131. Gebhardt, C.; Sevko, A.; Jiang, H.; Lichtenberger, R.; Reith, M.; Tarnanidis, K.; Holland-Letz, T.; Umansky, L.; Beckhove, P.; Sucker, A.; et al. Myeloid cells and related chronic inflammatory factors as novel predictive markers in melanoma treatment with ipilimumab. Clin. Cancer Res. 2015, 21, 5453-5459. [CrossRef]

132. Shirley, S.H.; Maltzan, K.V.; Robbins, P.O.; Kusewitt, D.F. Melanocyte and melanoma cell activation by calprotectin. J. Ski. Cancer 2014, 2014. [CrossRef] [PubMed]

133. Saha, A.; Lee, Y.-C.; Zhang, Z.; Chandra, G.; Su, S.-B.; Mukherjee, A.B. Lack of an endogenous anti-inflammatory protein in mice enhances colonization of B16F10 melanoma cells in the lungs. J. Biol. Chem. 2010, 285, 10822-10831. [CrossRef] [PubMed]

134. Ruma, I.M.W.; Putranto, E.W.; Kondo, E.; Murata, H.; Watanabe, M.; Huang, P.; Kinoshita, R.; Futami, J.; Inoue, Y.; Yamauchi, A.; et al. MCAM, as a novel receptor for S100A8/A9, mediates progression of malignant melanoma through prominent activation of NF-kB and ROS formation upon ligand binding. Clin. Exp. Metastasis 2016, 33, 609-627. [CrossRef] [PubMed]

135. Chen, Y.; Sumardika, I.W.; Tomonobu, N.; Winarsa Ruma, I.M.; Kinoshita, R.; Kondo, E.; Inoue, Y.; Sato, H.; Yamauchi, A.; Murata, H.; et al. Melanoma cell adhesion molecule is the driving force behind the dissemination of melanoma upon S100A8/A9 binding in the original skin lesion. Cancer Lett. 2019, 452, 178-190. [CrossRef] [PubMed]

136. Hibino, T.; Sakaguchi, M.; Miyamoto, S.; Yamamoto, M.; Motoyama, A.; Hosoi, J.; Shimokata, T.; Ito, T.; Tsuboi, R.; Huh, N.-H. S100A9 is a novel ligand of EMMPRIN that promotes melanoma metastasis. Cancer Res. 2013, 73, 172-183. [CrossRef]

137. Tomonobu, N.; Kinoshita, R.; Sakaguchi, M. S100 soil sensor receptors and molecular targeting therapy against them in cancer metastasis. Transl. Oncol. 2020, 13, 100753. [CrossRef]

138. Harpio, R.; Einarsson, R. S100 proteins as cancer biomarkers with focus on S100B in malignant melanoma. Clin. Biochem. 2004, 37, 512-518. [CrossRef]

139. Frauchiger, A.L.; Dummer, R.; Mangana, J. Serum S100B levels in melanoma. Methods Mol. Biol. 2019, 1929, 691-700. [CrossRef]

140. Kruijff, S.; Hoekstra, H.J. The current status of S-100B as a biomarker in melanoma. Eur. J. Surg. Oncol. 2012, 38, 281-285. [CrossRef]

141. Hartman, K.G.; Vitolo, M.I.; Pierce, A.D.; Fox, J.M.; Shapiro, P.; Martin, S.S.; Wilder, P.T.; Weber, D.J. Complex formation between S100B protein and the $\mathrm{p} 90$ ribosomal S6 kinase (RSK) in malignant melanoma is calcium-dependent and inhibits extracellular signal-regulated kinase (ERK)-mediated phosphorylation of RSK. J. Biol. Chem. 2014, 289, 12886-12895. [CrossRef]

142. Lin, J.; Yang, Q.; Yan, Z.; Markowitz, J.; Wilder, P.T.; Carrier, F.; Weber, D.J. Inhibiting S100B restores p53 levels in primary malignant melanoma cancer cells. J. Biol. Chem. 2004, 279, 34071-34077. [CrossRef] [PubMed]

143. Webster, M.R.; Fane, M.E.; Alicea, G.M.; Basu, S.; Kossenkov, A.V.; Marino, G.E.; Douglass, S.M.; Kaur, A.; Ecker, B.L.; Gnanapradeepan, K.; et al. Paradoxical role for wild-type p53 in driving therapy resistance in melanoma. Mol. Cell 2020, 77, 633-644.e635. [CrossRef] [PubMed]

144. Bai, Y.; Li, L.-D.; Li, J.; Lu, X. Prognostic values of S100 family members in ovarian cancer patients. BMC Cancer 2018, 18, 1256. [CrossRef] [PubMed]

145. Ma, N.; Zhu, L.; Yang, L.; Cui, Y.; Zhan, Y. Prognostic values of S100 family mRNA expression in ovarian cancer. Cancer Biomark. 2019, 25, 67-78. [CrossRef] [PubMed]

146. Izycka, N.; Sterzynska, K.; Januchowski, R.; Nowak-Markwitz, E. Semaphorin 3A (SEMA3A), protocadherin 9 (PCdh9), and S100 calcium binding protein A3 (S100A3) as potential biomarkers of carcinogenesis and chemoresistance of different neoplasms, including ovarian cancer-review of literature. Ginekol. Pol. 2019, 90, 223-227. [CrossRef] [PubMed]

147. Gillet, J.-P.; Calcagno, A.M.; Varma, S.; Davidson, B.; Bunkholt Elstrand, M.; Ganapathi, R.; Kamat, A.A.; Sood, A.K.; Ambudkar, S.V.; Seiden, M.V.; et al. Multidrug resistance-linked gene signature predicts overall survival of patients with primary ovarian serous carcinoma. Clin. Cancer Res. 2012, 18, 3197-3206. [CrossRef] 
148. Yang, T.; Cheng, J.; You, J.; Yan, B.; Liu, H.; Li, F. S100B promotes chemoresistance in ovarian cancer stem cells by regulating p53. Oncol. Rep. 2018, 40, 1574-1582. [CrossRef]

149. Yang, T.; Cheng, J.; Yang, Y.; Qi, W.; Zhao, Y.; Long, H.; Xie, R.; Zhu, B. S100B mediates stemness of ovarian cancer stem-like cells through inhibiting p53. Stem Cells 2017, 35, 325-336. [CrossRef]

150. Lokman, N.A.; Pyragius, C.E.; Ruszkiewicz, A.; Oehler, M.K.; Ricciardelli, C. Annexin A2 and S100A10 are independent predictors of serous ovarian cancer outcome. Transl. Res. 2016, 171, 83-95. [CrossRef]

151. Lokman, N.A.; Ho, R.; Gunasegaran, K.; Bonner, W.M.; Oehler, M.K.; Ricciardelli, C. Anti-tumour effects of all-trans retinoid acid on serous ovarian cancer. J. Exp. Clin. Cancer Res. 2019, 38, 10. [CrossRef]

152. Noye, T.M.; Lokman, N.A.; Oehler, M.K.; Ricciardelli, C. S100A10 and cancer hallmarks: Structure, functions, and its emerging role in ovarian cancer. Int. J. Mol. Sci. 2018, 19, 4122. [CrossRef] [PubMed]

153. Li, C.; Ma, Y.; Fei, F.; Zheng, M.; Li, Z.; Zhao, Q.; Du, J.; Liu, K.; Lu, R.; Zhang, S. Critical role and its underlying molecular events of the plasminogen receptor, S100A10 in malignant tumor and non-tumor diseases. J. Cancer 2020, 11, 826-836. [CrossRef] [PubMed]

154. Moravkova, P.; Kohoutova, D.; Rejchrt, S.; Cyrany, J.; Bures, J. Role of S100 proteins in colorectal carcinogenesis. Gastroenterol. Res. Pract. 2016, 2016. [CrossRef] [PubMed]

155. Hemandas, A.K.; Salto-Tellez, M.; Maricar, S.H.; Leong, A.F.P.K.; Leow, C.K. Metastasis-associated protein S100A4-a potential prognostic marker for colorectal cancer. J. Surg. Oncol. 2006, 93, 498-503. [CrossRef] [PubMed]

156. Cho, Y.-G.; Kim, C.-J.; Nam, S.-W.; Yoon, S.-H.; Lee, S.-H.; Yoo, N.-J.; Lee, J.-Y.; Park, W.-S. Overexpression of S100A4 is closely associated with progression of colorectal cancer. World J. Gastroenterol. 2005, 11, 4852-4856. [CrossRef] [PubMed]

157. Moris, D.; Spartalis, E.; Angelou, A.; Margonis, G.-A.; Papalambros, A.; Petrou, A.; Athanasiou, A.; Schizas, D.; Dimitroulis, D.; Felekouras, E. The value of calprotectin S100A8/A9 complex as a biomarker in colorectal cancer: A systematic review. JBUON 2016, 21, 859-866.

158. Hwang, C.-C.; Chai, H.-T.; Chen, H.-W.; Tsai, H.-L.; Lu, C.-Y.; Yu, F.-J.; Huang, M.-Y.; Wang, J.-Y. S100B protein expressions as an independent predictor of early relapse in UICC stages II and III colon cancer patients after curative resection. Ann. Surg. Oncol. 2011, 18, 139-145. [CrossRef]

159. Boye, K.; Nesland, J.M.; Sandstad, B.; Mælandsmo, G.M.; Flatmark, K. Nuclear S100A4 is a novel prognostic marker in colorectal cancer. Eur. J. Cancer 2010, 46, 2919-2925. [CrossRef]

160. Dahlmann, M.; Okhrimenko, A.; Marcinkowski, P.; Osterland, M.; Herrmann, P.; Smith, J.; Heizmann, C.W.; Schlag, P.M. RAGE mediates S100A4-induced cell motility via MAPK/ERK and hypoxia signaling and is a prognostic biomarker for human colorectal cancer metastasis. Oncotarget 2014, 5, 3220-3233. [CrossRef]

161. Wang, H.; Duan, L.; Zou, Z.; Li, H.; Yuan, S.; Chen, X.; Zhang, Y.; Li, X.; Sun, H.; Zha, H.; et al. Activation of the PI3K/Akt/mTOR/p70S6K pathway is involved in S100A4-induced viability and migration in colorectal cancer cells. Int. J. Med. Sci. 2014, 11, 841-849. [CrossRef]

162. Duan, L.; Wu, R.; Ye, L.; Wang, H.; Yang, X.; Zhang, Y.; Chen, X.; Zuo, G.; Zhang, Y.; Weng, Y.; et al. S100A8 and S100A9 are associated with colorectal carcinoma progression and contribute to colorectal carcinoma cell survival and migration via Wnt/ $\beta$-catenin pathway. PLoS ONE 2013, 8, e62092. [CrossRef]

163. Ichikawa, M.; Williams, R.; Wang, L.; Vogl, T.; Srikrishna, G. S100A8/A9 activate key genes and pathways in colon tumor progression. Mol. Cancer Res. 2011, 9, 133-148. [CrossRef] [PubMed]

164. Dong, L.; Wang, F.; Yin, X.; Chen, L.; Li, G.; Lin, F.; Ni, W.; Wu, J.; Jin, R.; Jiang, L. Overexpression of S100P promotes colorectal cancer metastasis and decreases chemosensitivity to 5-FU in vitro. Mol. Cell. Biochem. 2014, 389, 257-264. [CrossRef]

165. Jiang, L.; Lai, Y.-K.; Zhang, J.; Wang, H.; Lin, M.C.; He, M.-L.; Kung, H.-F. Targeting S100P inhibits colon cancer growth and metastasis by Lentivirus-mediated RNA interference and proteomic analysis. Mol. Med. 2011, 17, 709-716. [CrossRef]

166. Lin, F.; Zhang, P.; Zuo, Z.; Wang, F.; Bi, R.; Shang, W.; Wu, A.; Ye, J.; Li, S.; Sun, X.; et al. Thioredoxin-1 promotes colorectal cancer invasion and metastasis through crosstalk with S100P. Cancer Lett. 2017, 401, 1-10. [CrossRef]

167. Leclerc, E.; Vetter, S.W. The role of S100 proteins and their receptor RAGE in pancreatic cancer. Biochim. Biophys. Acta 2015, 1852, 2706-2711. [CrossRef] 
168. Ohuchida, K.; Mizumoto, K.; Miyasaka, Y.; Yu, J.; Cui, L.; Yamaguchi, H.; Toma, H.; Takahata, S.; Sato, N.; Nagai, E.; et al. Over-expression of S100A2 in pancreatic cancer correlates with progression and poor prognosis. J. Pathol. 2007, 213, 275-282. [CrossRef] [PubMed]

169. Biankin, A.V.; Kench, J.G.; Colvin, E.K.; Segara, D.; Scarlett, C.J.; Nguyen, N.Q.; Chang, D.K.; Morey, A.L.; Lee, C.-S.; Pinese, M.; et al. Expression of S100A2 calcium-binding protein predicts response to pancreatectomy for pancreatic cancer. Gastroenterology 2009, 137, 558-568, 568.e551-511. [CrossRef] [PubMed]

170. Ohuchida, K.; Mizumoto, K.; Ishikawa, N.; Fujii, K.; Konomi, H.; Nagai, E.; Yamaguchi, K.; Tsuneyoshi, M.; Tanaka, M. The role of S100A6 in pancreatic cancer development and its clinical implication as a diagnostic marker and therapeutic target. Clin. Cancer Res. 2005, 11, 7785-7793. [CrossRef]

171. Vimalachandran, D.; Greenhalf, W.; Thompson, C.; Luttges, J.; Prime, W.; Campbell, F.; Dodson, A.; Watson, R.; Crnogorac-Jurcevic, T.; Lemoine, N.; et al. High nuclear S100A6 (calcyclin) is significantly associated with poor survival in pancreatic cancer patients. Cancer Res. 2005, 65, 3218-3225. [CrossRef]

172. Ohuchida, K.; Mizumoto, K.; Ohhashi, S.; Yamaguchi, H.; Konomi, H.; Nagai, E.; Yamaguchi, K.; Tsuneyoshi, M.; Tanaka, M. S100A11, a putative tumor suppressor gene, is overexpressed in pancreatic carcinogenesis. Clin. Cancer Res. 2006, 12, 5417-5422. [CrossRef] [PubMed]

173. Xiao, M.-B.; Jiang, F.; Ni, W.-K.; Chen, B.-Y.; Lu, C.-H.; Li, X.-Y.; Ni, R.-Z. High expression of S100A11 in pancreatic adenocarcinoma is an unfavorable prognostic marker. Med. Oncol. 2012, 29, 1886-1891. [CrossRef]

174. Ohuchida, K.; Mizumoto, K.; Egami, T.; Yamaguchi, H.; Fujii, K.; Konomi, H.; Nagai, E.; Yamaguchi, K.; Tsuneyoshi, M.; Tanaka, M. S100P is an early developmental marker of pancreatic carcinogenesis. Clin. Cancer Res. 2006, 12, 5411-5416. [CrossRef] [PubMed]

175. Hu, H.; Zhang, Q.; Huang, C.; Shen, Y.; Chen, X.; Shi, X.; Tang, W. Diagnostic value of S100P for pancreatic cancer: A meta-analysis. Tumour Biol. 2014, 35, 9479-9485. [CrossRef] [PubMed]

176. Huang, S.; Zheng, J.; Huang, Y.; Song, L.; Yin, Y.; Ou, D.; He, S.; Chen, X.; Ouyang, X. Impact of S100A4 expression on clinicopathological characteristics and prognosis in pancreatic cancer: A meta-analysis. Dis. Markers 2016, 2016, 8137378. [CrossRef]

177. Ikenaga, N.; Ohuchida, K.; Mizumoto, K.; Yu, J.; Fujita, H.; Nakata, K.; Ueda, J.; Sato, N.; Nagai, E.; Tanaka, M. S100A4 mRNA is a diagnostic and prognostic marker in pancreatic carcinoma. J. Gastrointest. Surg. 2009, 13, 1852-1858. [CrossRef]

178. Tsukamoto, N.; Egawa, S.; Akada, M.; Abe, K.; Saiki, Y.; Kaneko, N.; Yokoyama, S.; Shima, K.; Yamamura, A.; Motoi, F.; et al. The expression of S100A4 in human pancreatic cancer is associated with invasion. Pancreas 2013, 42, 1027-1033. [CrossRef]

179. Rosty, C.; Ueki, T.; Argani, P.; Jansen, M.; Yeo, C.J.; Cameron, J.L.; Hruban, R.H.; Goggins, M. Overexpression of S100A4 in Pancreatic ductal adenocarcinomas is associated with poor differentiation and DNA hypomethylation. Am. J. Pathol. 2002, 160, 45-50. [CrossRef]

180. Tabata, T.; Tsukamoto, N.; Fooladi, A.A.I.; Yamanaka, S.; Furukawa, T.; Ishida, M.; Sato, D.; Gu, Z.; Nagase, H.; Egawa, S.; et al. RNA interference targeting against S100A4 suppresses cell growth and motility and induces apoptosis in human pancreatic cancer cells. Biochem. Biophys. Res. Commun. 2009, 390, 475-480. [CrossRef]

181. Sekine, H.; Chen, N.; Sato, K.; Saiki, Y.; Yoshino, Y.; Umetsu, Y.; Jin, G.; Nagase, H.; Gu, Z.; Fukushige, S.; et al. S100A4, frequently overexpressed in various human cancers, accelerates cell motility in pancreatic cancer cells. Biochem. Biophys. Res. Commun. 2012, 429, 214-219. [CrossRef]

182. Mahon, P.C.; Baril, P.; Bhakta, V.; Chelala, C.; Caulee, K.; Harada, T.; Lemoine, N.R. S100A4 contributes to the suppression of BNIP3 expression, chemoresistance, and inhibition of apoptosis in pancreatic cancer. Cancer Res. 2007, 67, 6786-6795. [CrossRef] [PubMed]

183. Xu, X.; Su, B.; Xie, C.; Wei, S.; Zhou, Y.; Liu, H.; Dai, W.; Cheng, P.; Wang, F.; Xu, X.; et al. Sonic hedgehog-Gli1 signaling pathway regulates the epithelial mesenchymal transition (EMT) by mediating a new target gene, S100A4, in pancreatic cancer cells. PLoS ONE 2014, 9, e96441. [CrossRef] [PubMed]

184. Che, P.; Yang, Y.; Han, X.; Hu, M.; Sellers, J.C.; Londono-Joshi, A.I.; Cai, G.-Q.; Buchsbaum, D.J.; Christein, J.D.; Tang, Q.; et al. S100A4 promotes pancreatic cancer progression through a dual signaling pathway mediated by Src and focal adhesion kinase. Sci. Rep. 2015, 5, 8453. [CrossRef] [PubMed]

185. Sheikh, A.A.; Vimalachandran, D.; Thompson, C.C.; Jenkins, R.E.; Nedjadi, T.; Shekouh, A.; Campbell, F.; Dodson, A.; Prime, W.; Crnogorac-Jurcevic, T.; et al. The expression of S100A8 in pancreatic cancer-associated monocytes is associated with the Smad4 status of pancreatic cancer cells. Proteomics 2007, 7, 1929-1940. [CrossRef] 
186. Ang, C.W.; Nedjadi, T.; Sheikh, A.A.; Tweedle, E.M.; Tonack, S.; Honap, S.; Jenkins, R.E.; Park, B.K.; Schwarte-Waldhoff, I.; Khattak, I.; et al. Smad4 loss is associated with fewer S100A8-positive monocytes in colorectal tumors and attenuated response to S100A8 in colorectal and pancreatic cancer cells. Carcinogenesis 2010, 31, 1541-1551. [CrossRef]

187. Hermani, A.; Hess, J.; DeServi, B.; Medunjanin, S.; Grobholz, R.; Trojan, L.; Angel, P.; Mayer, D. Calcium-binding proteins S100A8 and S100A9 as novel diagnostic markers in human prostate cancer. Clin. Cancer Res. 2005, 11, 5146-5152. [CrossRef]

188. Hermani, A.; Servi, B.D.; Medunjanin, S.; Tessier, P.A.; Mayer, D. S100A8 and S100A9 activate MAP kinase and NF-kappaB signaling pathways and trigger translocation of RAGE in human prostate cancer cells. Exp. Cell Res. 2006, 312, 184-197. [CrossRef]

189. Rehman, I.; Cross, S.S.; Azzouzi, A.-R.; Catto, J.W.F.; Deloulme, J.C.; Larre, S.; Champigneuille, J.; Fromont, G.; Cussenot, O.; Hamdy, F.C. S100A6 (Calcyclin) is a prostate basal cell marker absent in prostate cancer and its precursors. Br. J. Cancer 2004, 91, 739-744. [CrossRef]

190. Yao, R.; Lopez-Beltran, A.; Maclennan, G.T.; Montironi, R.; Eble, J.N.; Cheng, L. Expression of S100 Protein family members in the pathogenesis of bladder tumors. Anticancer Res. 2007, 27, 3051-3058.

191. Ha, Y.-S.; Kim, M.-J.; Yoon, H.-Y.; Kang, H.-W.; Kim, Y.-J.; Yun, S.-J.; Lee, S.-C.; Kim, W.-J. mRNA expression of S100A8 as a prognostic marker for progression of non-muscle-invasive bladder cancer. Korean J. Urol. 2010, 51, 15-20. [CrossRef]

192. Kim, S.-K.; Kim, E.-J.; Leem, S.-H.; Ha, Y.-S.; Kim, Y.-J.; Kim, W.-J. Identification of S100A8-correlated genes for prediction of disease progression in non-muscle invasive bladder cancer. BMC Cancer 2010, 10, 21. [CrossRef] [PubMed]

193. Shiota, M.; Tsunoda, T.; Song, Y.; Yokomizo, A.; Tada, Y.; Oda, Y.; Naito, S. Enhanced S100 calcium-binding protein P expression sensitizes human bladder cancer cells to cisplatin. BJU Int. 2011, 107, 1148-1153. [CrossRef] [PubMed]

194. Cho, K.; Ro, S.W.; Seo, S.H.; Jeon, Y.; Moon, H.; Kim, D.Y.; Kim, S.U. Genetically engineered mouse models for liver cancer. Cancers 2019, 12, 14. [CrossRef] [PubMed]

195. Zhai, X.; Zhu, H.; Wang, W.; Zhang, S.; Zhang, Y.; Mao, G. Abnormal expression of EMT-related proteins, S100A4, vimentin and E-cadherin, is correlated with clinicopathological features and prognosis in HCC. Med. Oncol. 2014, 31, 970. [CrossRef]

196. Jiao, J.; González, Á.; Stevenson, H.L.; Gagea, M.; Sugimoto, H.; Kalluri, R.; Beretta, L. Depletion of S100A4+ stromal cells does not prevent HCC development but reduces the stem cell-like phenotype of the tumors. Exp. Mol. Med. 2018, 50, 422. [CrossRef]

197. Li, Y.; Wang, J.; Song, K.; Liu, S.; Zhang, H.; Wang, F.; Ni, C.; Zhai, W.; Liang, J.; Qin, Z.; et al. S100A4 promotes hepatocellular carcinogenesis by intensifying fibrosis-associated cancer cell stemness. Oncoimmunology 2020, 9, 1725355. [CrossRef]

198. Zhao, F.-T.; Jia, Z.-S.; Yang, Q.; Song, L.; Jiang, X.-J. S100A14 promotes the growth and metastasis of hepatocellular carcinoma. Asian Pac. J. Cancer Prev. 2013, 14, 3831-3836. [CrossRef]

199. Mohamed, B.F.; Serag, W.M.; Abdelal, R.M.; Elsergany, H.F. S100A14 protein as diagnostic and prognostic marker in hepatocellular carcinoma. Egypt. Liver J. 2019, 9. [CrossRef]

200. Raffat, M.A.; Hadi, N.I.; Hosein, M.; Mirza, S.; Ikram, S.; Akram, Z. S100 proteins in oral squamous cell carcinoma. Clin. Chim. Acta 2018, 480, 143-149. [CrossRef]

201. Sapkota, D.; Bruland, O.; Costea, D.E.; Haugen, H.; Vasstrand, E.N.; Ibrahim, S.O. S100A14 regulates the invasive potential of oral squamous cell carcinoma derived cell-lines in vitro by modulating expression of matrix metalloproteinases, MMP1 and MMP9. Eur. J. Cancer 2011, 47, 600-610. [CrossRef]

202. Sapkota, D.; Costea, D.E.; Blø, M.; Bruland, O.; Lorens, J.B.; Vasstrand, E.N.; Ibrahim, S.O. S100A14 inhibits proliferation of oral carcinoma derived cells through G1-arrest. Oral Oncol. 2012, 48, 219-225. [CrossRef]

203. White, R.; Pulford, E.; Elliot, D.J.; Thurgood, L.A.; Klebe, S. Quantitative mass spectrometry to identify protein markers for diagnosis of malignant pleural mesothelioma. J. Proteom. 2019, 192, 374-382. [CrossRef] [PubMed]

204. Nader, J.S.; Guillon, J.; Petit, C.; Boissard, A.; Franconi, F.; Blandin, S.; Lambot, S.; Grégoire, M.; Verrièle, V.; Nawrocki-Raby, B.; et al. S100A4 is a biomarker of tumorigenesis, EMT, invasion, and colonization of host organs in experimental malignant mesothelioma. Cancers 2020, 12, 939. [CrossRef] [PubMed] 
205. Hussain, S.F.; Kong, L.Y.; Jordan, J.; Conrad, C.; Madden, T.; Fokt, I.; Priebe, W.; Heimberger, A.B. A novel small molecule inhibitor of signal transducers and activators of transcription 3 reverses immune tolerance in malignant glioma patients. Cancer Res. 2007, 67, 9630-9636. [CrossRef] [PubMed]

206. Kostianovsky, A.M.; Maier, L.M.; Anderson, R.C.; Bruce, J.N.; Anderson, D.E. Astrocytic regulation of human monocytic/microglial activation. J. Immunol. 2008, 181, 5425-5432. [CrossRef]

207. Hwang, J.S.; Jung, E.H.; Kwon, M.Y.; Han, I.O. Glioma-secreted soluble factors stimulate microglial activation: The role of interleukin-1 $\beta$ and tumor necrosis factor- $\alpha$. J. Neuroimmunol. 2016, 298, 165-171. [CrossRef]

208. Yang, I.; Han, S.J.; Kaur, G.; Crane, C.; Parsa, A.T. The role of microglia in central nervous system immunity and glioma immunology. J. Clin. Neurosci. 2010, 17, 6-10. [CrossRef]

209. Zhang, L.; Liu, W.; Alizadeh, D.; Zhao, D.; Farrukh, O.; Lin, J.; Badie, S.A.; Badie, B. S100B attenuates microglia activation in gliomas: Possible role of STAT3 pathway. Glia 2011, 59, 486-498. [CrossRef]

210. Wang, H.; Zhang, L.; Zhang, I.Y.; Chen, X.; Da Fonseca, A.; Wu, S.; Ren, H.; Badie, S.; Sadeghi, S.; Ouyang, M.; et al. S100B promotes glioma growth through chemoattraction of myeloid-derived macrophages. Clin. Cancer Res. 2013, 19, 3764-3775. [CrossRef]

211. Gao, H.; Zhang, I.Y.; Zhang, L.; Song, Y.; Liu, S.; Ren, H.; Liu, H.; Zhou, H.; Su, Y.; Yang, Y.; et al. S100B suppression alters polarization of infiltrating myeloid-derived cells in gliomas and inhibits tumor growth. Cancer Lett. 2018, 439, 91-100. [CrossRef]

212. Holla, F.K.; Postma, T.J.; Blankenstein, M.A.; van Mierlo, T.J.M.; Vos, M.J.; Sizoo, E.M.; de Groot, M.; Uitdehaag, B.M.J.; Buter, J.; Klein, M.; et al. Prognostic value of the S100B protein in newly diagnosed and recurrent glioma patients: A serial analysis. J. Neuro-Oncol. 2016, 129, 525-532. [CrossRef]

213. Gonzalez, L.L.; Garrie, K.; Turner, M.D. Role of S100 proteins in health and disease. Biochim. Biophys. Acta Mol. Cell Res. 2020, 1867, 118677. [CrossRef]

214. Sack, U.; Walther, W.; Scudiero, D.; Selby, M.; Aumann, J.; Lemos, C.; Fichtner, I.; Schlag, P.M.; Shoemakere, R.H.; Stein, U. S100A4-induced cell motility and metastasis is restricted by the Wnt/ $\beta$-catenin pathway inhibitor calcimycin in colon cancer cells. Mol. Biol. Cell 2011, 22, 3344-3354. [CrossRef]

215. Stein, U.; Arlt, F.; Smith, J.; Sack, U.; Herrmann, P.; Walther, W.; Lemm, M.; Fichtner, I.; Shoemaker, R.H.; Schlag, P.M. Intervening in $\beta$-catenin signaling by sulindac inhibits S100A4-dependent colon cancer metastasis. Neoplasia 2011, 13, 131-144. [CrossRef]

216. Sack, U.; Walther, W.; Scudiero, D.; Selby, M.; Kobelt, D.; Lemm, M.; Fichtner, I.; Schlag, P.M.; Shoemaker, R.H.; Stein, U. Novel effect of antihelminthic Niclosamide on S100A4-mediated metastatic progression in colon cancer. J. Natl. Cancer Inst. 2011, 103, 1018-1036. [CrossRef]

217. Burock, S.; Daum, S.; Keilholz, U.; Neumann, K.; Walther, W.; Stein, U. Phase II trial to investigate the safety and efficacy of orally applied niclosamide in patients with metachronous or sychronous metastases of a colorectal cancer progressing after therapy: The NIKOLO trial. BMC Cancer 2018, 18, 297. [CrossRef]

218. Garrett, S.C.; Hodgson, L.; Rybin, A.; Toutchkine, A.; Hahn, K.M.; Lawrence, D.S.; Bresnick, A.R. A biosensor of S100A4 metastasis factor activation: Inhibitor screening and cellular activation dynamics. Biochemistry 2008, 47, 986-996. [CrossRef]

219. Malashkevich, V.N.; Dulyaninova, N.G.; Ramagopal, U.A.; Liriano, M.A.; Varney, K.M.; Knight, D.; Brenowitz, M.; Weber, D.J.; Almo, S.C.; Bresnick, A.R. Phenothiazines inhibit S100A4 function by inducing protein oligomerization. Proc. Natl. Acad. Sci. USA 2010, 107, 8605-8610. [CrossRef]

220. Raymond, E.; Dalgleish, A.; Damber, J.-E.; Smith, M.; Pili, R. Mechanisms of action of tasquinimod on the tumour microenvironment. Cancer Chemother. Pharmacol. 2014, 73, 1-8. [CrossRef]

221. Shen, L.; Sundstedt, A.; Ciesielski, M.; Miles, K.M.; Celander, M.; Adelaiye, R.; Orillion, A.; Ciamporcero, E.; Ramakrishnan, S.; Ellis, L.; et al. Tasquinimod modulates suppressive myeloid cells and enhances cancer immunotherapies in murine models. Cancer Immunol. Res. 2015, 3, 136-148. [CrossRef]

222. Shen, L.; Pili, R. Tasquinimod targets suppressive myeloid cells in the tumor microenvironment. Oncoimmunology 2019, 8. [CrossRef] [PubMed]

223. Sternberg, C.; Armstrong, A.; Pili, R.; Ng, S.; Huddart, R.; Agarwal, N.; Khvorostenko, D.; Lyulko, O.; Brize, A.; Vogelzang, N.; et al. Randomized, double-blind, placebo-controlled phase III study of tasquinimod in men with metastatic castration-resistant prostate cancer. J. Clin. Oncol. 2016, 34, 2636-2643. [CrossRef]

224. Reddy, T.R.K.; Li, C.; Fischer, P.M.; Dekker, L.V. Three-dimensional pharmacophore design and biochemical screening identifies substituted 1,2,4-triazoles as inhibitors of the annexin A2-S100A10 protein interaction. ChemMedChem 2012, 7, 1435-1446. [CrossRef] 
225. Reddy, T.R.K.; Li, C.; Guo, X.; Fischer, P.M.; Dekker, L.V. Design, synthesis and SAR exploration of tri-substituted 1,2,4-triazoles as inhibitors of the annexin A2-S100A10 protein interaction. Bioorganic Med. Chem. 2014, 22, 5378-5391. [CrossRef]

226. Markowitz, J.; Chen, I.; Gitti, R.; Baldisseri, D.M.; Pan, Y.; Udan, R.; Carrier, F.; MacKerell, A.D.; Weber, D.J. Identification and characterization of small molecule inhibitors of the calcium-dependent S100B-p53 tumor suppressor interaction. J. Med. Chem. 2004, 47, 5085-5093. [CrossRef]

227. Smith, J.; Stewart, B.J.; Glaysher, S.; Peregrin, K.; Knight, L.A.; Weber, D.J.; Cree, I.A. The effect of pentamidine on melanoma ex vivo. Anti-Cancer Drugs 2010, 21, 181-185. [CrossRef]

228. Mehnert, J.M.; Hausner, P.F.; Tan, M.; Weber, D.; Sausville, E.A. Treatment of melanoma with wild-type p53 (wtp53) and detectable S100B using pentamidine: A phase II trial with correlative biomarker endpoints. J. Clin. Oncol. 2010, 28, TPS310. [CrossRef]

229. Arumugam, T.; Ramachandran, V.; Logsdon, C.D. Effect of cromolyn on S100P interactions with RAGE and pancreatic cancer growth and invasion in mouse models. J. Natl. Cancer Inst. 2006, 98, 1806-1818. [CrossRef]

230. Penumutchu, S.R.; Chou, R.-H.; Yu, C. Interaction between S100P and the anti-allergy drug cromolyn. Biochem. Biophys. Res. Commun. 2014, 454, 404-409. [CrossRef]

231. Arumugam, T.; Ramachandran, V.; Sun, D.; Peng, Z.; Pal, A.; Maxwell, D.S.; Bornmann, W.G.; Logsdon, C.D. Designing and developing S100P inhibitor 5-methyl cromolyn for pancreatic cancer therapy. Mol. Cancer Ther. 2013, 12, 654-662. [CrossRef]

232. Klingelhöfer, J.; Grum-Schwensen, B.; Beck, M.K.; Knudsen, R.S.P.; Grigorian, M.; Lukanidin, E.; Ambartsumian, N. Anti-S100A4 antibody suppresses metastasis formation by blocking stroma cell invasion. Neoplasia 2012, 14, 1260-1268. [CrossRef] [PubMed]

233. Grum-Schwensen, B.; Klingelhöfer, J.; Beck, M.; Bonefeld, C.M.; Hamerlik, P.; Guldberg, P.; Grigorian, M.; Lukanidin, E.; Ambartsumian, N. S100A4-neutralizing antibody suppresses spontaneous tumor progression, pre-metastatic niche formation and alters T-cell polarization balance. BMC Cancer 2015, 15, 44. [CrossRef] [PubMed]

234. Hernández, J.L.; Padilla, L.; Dakhel, S.; Coll, T.; Hervas, R.; Adan, J.; Masa, M.; Mitjans, F.; Martinez, J.M.; Coma, S.; et al. Therapeutic targeting of tumor growth and angiogenesis with a novel anti-S100A4 monoclonal antibody. PLoS ONE 2013, 8, e72480. [CrossRef] [PubMed]

235. Padilla, L.; Dakhel, S.; Adan, J.; Masa, M.; Martinez, J.M.; Roque, L.; Coll, T.; Hervas, R.; Calvis, C.; Llinas, L.; et al. S100A7: From mechanism to cancer therapy. Oncogene 2017, 36, 6749-6761. [CrossRef]

236. Kinoshita, R.; Sato, H.; Yamauchi, A.; Takahashi, Y.; Inoue, Y.; Sumardika, I.W.; Chen, Y.; Tomonobu, N.; Araki, K.; Shien, K.; et al. Newly developed anti-S100A8/A9 monoclonal antibody efficiently prevents lung tropic cancer metastasis. Int. J. Cancer 2019, 145, 569-575. [CrossRef]

237. Dakhel, S.; Padilla, L.; Adan, J.; Masa, M.; Martinez, J.M.; Roque, L.; Coll, T.; Hervas, R.; Calvis, C.; Messeguer, R.; et al. S100P antibody-mediated therapy as a new promising strategy for the treatment of pancreatic cancer. Oncogenesis 2014, 3, 92. [CrossRef]

238. Dou, C.; Liu, Z.; Xu, M.; Jia, Y.; Wang, Y.; Li, Q.; Yang, W.; Zheng, X.; Tu, K.; Liu, Q. miR-187-3p inhibits the metastasis and epithelial-mesenchymal transition of hepatocellular carcinoma by targeting S100A4. Cancer Lett. 2016, 381, 380-390. [CrossRef]

239. Yang, D.; Du, G.; Xu, A.; Xi, X.; Li, D. Expression of miR-149-3p inhibits proliferation, migration, and invasion of bladder cancer by targeting S100A4. Am. J. Cancer Res. 2017, 7, 2209-2219.

240. Li, P.; Lv, X.; Zhang, Z.; Xie, S. S100A6/miR193a regulates the proliferation, invasion, migration and angiogenesis of lung cancer cells through the P53 acetylation. Am. J. Transl. Res. 2019, 11, 4634-4649.

241. Fan, F.; Lu, J.; Yu, W.; Zhang, Y.; Xu, S.; Pang, L.; Zhu, B. MicroRNA-26b-5p regulates cell proliferation, invasion and metastasis in human intrahepatic cholangiocarcinoma by targeting S100A7. Oncol. Lett. 2018, 15, 386-392. [CrossRef]

242. Guo, Y.; Fu, W.; Chen, H.; Shang, C.; Zhong, M. miR-24 functions as a tumor suppressor in Hep2 laryngeal carcinoma cells partly through down-regulation of the S100A8 protein. Oncol. Rep. 2012, 27, 1097-1103. [CrossRef]

243. Lang, B.; Shang, C.; Meng, L. Targeted silencing of S100A8 gene by miR-24 to increase chemotherapy sensitivity of endometrial carcinoma cells to paclitaxel. Med. Sci. Monit. 2016, 22, 1953-1958. [CrossRef] 
244. Lv, H.; Hou, H.; Lei, H.; Nie, C.; Chen, B.; Bie, L.; Han, L.; Chen, X. MicroRNA-6884-5p regulates the proliferation, invasion and EMT of gastric cancer cells by directly targeting S100A16. Oncol. Res. 2019, 28, 225-236. [CrossRef]

245. Zhong, S.; Jeong, J.-H.; Chen, Z.; Chen, Z.; Luo, J.-L. Targeting tumor microenvironment by small-molecule inhibitors. Transl. Oncol. 2020, 13, 57-69. [CrossRef]

246. Lavanya, V.; Adil, M.; Ahmed, N.; Rishi, A.K.; Jamal, S. Small molecule inhibitors as emerging cancer therapeutics. Integr. Cancer Sci. Therap. 2014, 1, 39-46. [CrossRef]

247. Bresnick, A.R. S100 proteins as therapeutic targets. Biophys. Rev. 2018, 10, 1617-1629. [CrossRef]

248. Gasser, M.; Waaga-Gasser, A.M. Therapeutic antibodies in cancer therapy. Adv. Exp. Med. Biol. 2016, 917, 95-120. [CrossRef]

249. Lu, R.-M.; Hwang, Y.-C.; Liu, I.-J.; Lee, C.-C.; Tsai, H.-Z.; Li, H.-J.; Wu, H.-C. Development of therapeutic antibodies for the treatment of diseases. J. Biomed. Sci. 2020, 27, 1. [CrossRef]

250. Marrocco, I.; Romaniello, D.; Yarden, Y. Cancer immunotherapy: The dawn of antibody cocktails. Methods Mol. Biol. 2019, 1904, 11-51. [CrossRef]

251. Almagro, J.C.; Daniels-Wells, T.R.; Perez-Tapia, S.M.; Penichet, M.L. Progress and challenges in the design and clinical development of antibodies for cancer therapy. Front. Immunol. 2017, 8, 1751. [CrossRef]

252. Cruz, E.; Kayser, V. Monoclonal antibody therapy of solid tumors: Clinical limitations and novel strategies to enhance treatment efficacy. Biol. Targets Ther. 2019, 13, 33-51. [CrossRef] [PubMed]

253. Dufresne, S.; Rébillard, A.; Muti, P.; Friedenreich, C.M.; Brenner, D.R. A review of physical activity and circulating mirna expression: Implications in cancer risk and progression. Cancer Epidemiol. Biomark. Prev. 2018, 27, 11-24. [CrossRef] [PubMed]

254. Ors-Kumoglu, G.; Gulce-Iz, S.; Biray-Avci, C. Therapeutic microRNAs in human cancer. Cytotechnology 2019, 71, 411-425. [CrossRef] [PubMed]

255. Ganju, A.; Khan, S.; Hafeez, B.B.; Behrman, S.W.; Yallapu, M.M.; Chauhan, S.C.; Jaggi, M. miRNA nanotherapeutics for cancer. Drug Discov. Today 2017, 22, 424-432. [CrossRef] [PubMed]

256. Wright, N.T.; Cannon, B.R.; Zimmer, D.B.; Weber, D.J. S100A1: Structure, function, and therapeutic potential. Curr. Chem. Biol. 2009, 3, 138-145. [CrossRef]

257. Kizawa, K.; Takahara, H.; Unno, M.; Heizmann, C.W. S100 and S100 fused-type protein families in epidermal maturation with special focus on S100A3 in mammalian hair cuticles. Biochimie 2011, 93, 2038-2047. [CrossRef]

258. Kizawa, K.; Fujimori, T.; Kawai, T. Arachidonate 12-lipoxygenase inhibitors promote S100A3 citrullination in cultured SW480 cells and isolated hair follicles. Biol. Pharm. Bull. 2017, 40, 516-523. [CrossRef]

259. Bertini, I.; Das Gupta, S.; Hu, X.; Karavelas, T.; Luchinat, C.; Parigi, G.; Yuan, J. Solution structure and dynamics of S100A5 in the apo and Ca2+-bound states. J. Biol. Inorg. Chem. 2009, 14, 1097-1107. [CrossRef]

260. Jurewicz, E.; Wyroba, E.; Filipek, A. Tubulin-dependent secretion of S100A6 and cellular signaling pathways activated by S100A6-integrin $\beta 1$ interaction. Cell. Signal. 2018, 42, 21-29. [CrossRef]

261. Rosenberger, S.; Thorey, I.S.; Werner, S.; Boukamp, P. A novel regulator of telomerase. S100A8 mediates differentiation-dependent and calcium-induced inhibition of telomerase activity in the human epidermal keratinocyte line HaCaT. J. Biol. Chem. 2007, 282, 6126-6135. [CrossRef]

262. Pietzsch, J.; Hoppmann, S. Human S100A12: A novel key player in inflammation? Amino Acids 2009, 36, 381-389. [CrossRef] [PubMed]

263. Yang, Z.; Tao, T.; Raftery, M.J.; Youssef, P.; Girolamo, N.D.; Geczy, C.L. Proinflammatory properties of the human S100 protein S100A12. J. Leukoc. Biol. 2001, 69, 986-994. [PubMed]

264. Bagheri, V. S100A12: Friend or foe in pulmonary tuberculosis? Cytokine 2017, 92, 80-82. [CrossRef] [PubMed]

265. Ridinger, K.; Schäfer, B.W.; Durussel, I.; Cox, J.A.; Heizmann, C.W. S100A13-biochemical characterization and subcellular localization in different cell lines. J. Biol. Chem. 2000, 275, 8686-8694. [CrossRef] [PubMed]

266. Massi, D.; Landriscina, M.; Piscazzi, A.; Cosci, E.; Kirov, A.; Paglierani, M.; Di Serio, C.; Mourmouras, V.; Fumagalli, S.; Biagioli, M.; et al. S100A13 is a new angiogenic marker in human melanoma. Mod. Pathol. 2010, 23, 804-813. [CrossRef] [PubMed]

267. Mohan, S.K.; Yu, C. The IL1alpha-S100A13 heterotetrameric complex structure: A component in the non-classical pathway for interleukin 1alpha secretion. J. Biol. Chem. 2011, 286, 14608-14617. [CrossRef] 
268. Chen, Y.-C.; Chen, D.; Sung, M.-T.; Chen, C.-J.; Wang, T.-Y.; Lin, Y.-Y.; Lin, M.-C.; Chang, H.-C.; Chen, Y.-M.; Hsiao, C.-C.; et al. Increased S100A15 expression and decreased DNA methylation of its gene promoter are involved in high metastasis potential and poor outcome of lung adenocarcinoma. Oncotarget 2017, 8, 45710-45724. [CrossRef]

269. Liu, Y.; Zhang, R.; Xin, J.; Sun, Y.; Li, J.; Wei, D.; Zhao, A.Z. Identification of S100A16 as a novel adipogenesis promoting factor in 3T3-L1 cells. Endocrinology 2011, 152, 903-911. [CrossRef]

270. Sturchler, E.; Cox, J.A.; Durussel, I.; Weibel, M.; Heizmann, C.W. S100A16, a novel calcium-binding protein of the EF-hand superfamily. J. Biol. Chem. 2006, 281, 38905-38917. [CrossRef]

271. Sorci, G.; Riuzzi, F.; Arcuri, C.; Tubaro, C.; Bianchi, R.; Giambanco, I. S100B protein in tissue development, repair and regeneration. World J. Biol. Chem. 2013, 4, 1-12. [CrossRef]

272. Jiang, H.; Hu, H.; Tong, X.; Jiang, Q.; Zhu, H.; Zhang, S. Calcium-binding protein S100P and cancer: Mechanisms and clinical relevance. J. Cancer Res. Clin. Oncol. 2012, 138, 1-9. [CrossRef] [PubMed]

(C) 2020 by the authors. Licensee MDPI, Basel, Switzerland. This article is an open access article distributed under the terms and conditions of the Creative Commons Attribution (CC BY) license (http://creativecommons.org/licenses/by/4.0/). 